Canadian Science Publishing

Canadian Journal of Earth Sciences Revue canadienne des sciences de la Terre

\title{
Geochemistry of volcanic and plutonic rocks from the Nahlin ophiolite with implications for a Permo-Triassic arc in the Cache Creek terrane, northwestern British Columbia
}

\begin{tabular}{|r|l|}
\hline Journal: & Canadian Journal of Earth Sciences \\
\hline Manuscript ID & cjes-2017-0069.R1 \\
\hline Manuscript Type: & Article \\
\hline Date Submitted by the Author: & 05 -Jul-2017 \\
\hline $\begin{array}{r}\text { Complete List of Authors: } \\
\text { Is the invited manuscript for } \\
\text { consideration in a Special } \\
\text { Issue? : }\end{array}$ & $\begin{array}{l}\text { Zagorevski, Alex; Geological Survey of Canada } \\
\text { Canil, Dante; School of Earth and Ocean Sciences }\end{array}$ \\
\hline Keyword: & igneous rocks, ophiolite, arc, geochemistry, Cordillera \\
\hline
\end{tabular}


1 Geochemistry of volcanic and plutonic rocks from the Nahlin ophiolite with implications for a Permo-Triassic arc in the Cache Creek terrane, northwestern British Columbia

S. McGoldrick, School of Earth and Ocean Sciences, University of Victoria, Victoria, BC, smcgold@uvic.ca

A. Zagorevski, Geological Survey of Canada, Ottawa, ON alex.zagorevski@canada.ca

D. Canil*, School of Earth and Ocean Sciences, University of Victoria, Victoria, BC dcanil@uvic.ca

11

- corresponding author 


\section{Abstract}

22 In northwestern British Columbia, the Permian Nahlin ophiolite in the northern Cache Creek

23 terrane comprises spinel harzburgite tectonite with minor lherzolite, lower crustal mafic and

24 ultramafic cumulates, gabbroic rocks including dikes intruding mantle harzburgite, and basaltic

volcanic and volcaniclastic rocks. New lithogeochemical data from the Menatatuline Range area confirm that plutonic and volcanic rocks of the ophiolite are tholeiitic and arc-related, while only a minor component of volcanic rocks are alkaline intraplate basalts. Tholeiitic basalts of the Nahlin ophiolite represent the products of $2-20 \%$ fractional melting, and their complementary residue may be peridotite from the ophiolite mantle section. Correlative tholeiitic volcanic sections can be found elsewhere in the northern Cache Creek terrane, and may be linked to a regionally extensive $(\sim 200 \mathrm{~km})$ intraoceanic arc. The arc tholeiite geochemistry of the plutonic and volcanic rocks, and the highly depleted nature of the mantle residues imply that the Nahlin ophiolite formed in a supra-subduction zone (SSZ) environment. The Nahlin ophiolite therefore occupied the upper plate during intraoceanic collision prior to emplacement of the Cache Creek terrane. The volumetrically minor OIB-type volcanic rocks in the northern Cache Creek terrane are associated with carbonate successions bearing Tethyan fauna. These sequences are likely fragments of oceanic plateaux and their carbonate atolls sliced off of the subducting plate, and 38 are unrelated to the Nahlin ophiolite - arc system.

Introduction

Ophiolites are ubiquitous features of Phanerozoic orogens where they represent

41 fragments of oceanic lithosphere preserved along suture zones. Upper Paleozoic-Lower

42 Mesozoic ophiolites exposed throughout the Canadian Cordillera are commonly interpreted to 43 mark remnants of closed ocean basins (e.g., Tempelman-Kluit 1979, Ash and Arksey 1990, 
44 Struik et al. 2001). The Cache Creek terrane in northwestern British Columbia preserves aerially 45 extensive ophiolites, but few detailed petrological and geochemical studies of these rocks have 46 been carried out, despite their importance to tectonic models of the Cordillera (Terry 1977, Ash 47 and Arksey 1990, Ash 1994, Canil et al. 2006). Herein we build on work by English et al. (2010) in the northern Cache Creek terrane, which identified two distinct magma suites in this region: abundant subalkaline plutonic and volcanic rocks with arc signatures, and minor alkaline withinplate volcanic rocks, an association also noted in central British Columbia (Tardy et al. 2001, Lapierre et al. 2003). The close spatial association of volcanic rocks originating in two different plate settings has implications for the emplacement of the Nahlin ophiolite, and models involving closure of ocean basin for Cache Creek terrane accretion, and overall continental growth in the northern Cordillera.

In this contribution, we investigate the geological relationships and petrochemistry of the Nahlin ophiolite and adjacent rocks in the Menatatuline Range area of northern British Columbia. The Nahlin ophiolite is the largest, best-preserved and well-exposed ophiolite in the Cache Creek terrane (Figure 1; Table 1), however, due to its remote location it has not been investigated in detail since Terry (1977). We present new field and lithogeochemical data constraining the relationships between mantle, lower crustal and supracrustal rocks in the Nahlin ophiolite, and the spatial connection to accreted alkaline basalt and carbonate platform sequence.

\section{Regional Geology}

The Mississippian to Lower Jurassic Cache Creek terrane is discontinuously exposed through British Columbia and southern Yukon and is bound by the peri-Laurentian YukonTanana, Quesnellia and Stikinia terranes. Permian carbonate rocks of the Cache Creek terrane contain Tethyan fauna that is distinct from that in adjacent Stikinia and Quesnellia, indicating 
that parts of the Cache Creek terrane are exotic with respect to Laurentia and adjacent terranes (Monger and Ross 1971, Orchard et al. 2001). The Cache Creek and adjacent terranes were amalgamated and stitched together by crosscutting plutons by the Middle Jurassic (Gabrielse 1991, Mihalynuk et al. 1992, 1998). The aforementioned contrasting faunal assemblages between the accreted terranes has strongly influenced tectonic models for the northern Cordillera (e.g., Mihalynuk et al. 1994, Johnston and Borel 2007). Although central to several such models, the tectono-stratigraphy and tectonic setting of the Cache Creek terrane remain poorly understood. Some authors treat the whole or parts of the Cache Creek terrane as a subduction zone melange or an accretionary complex (e.g., Mihalynuk et al. 1994, 2004b, Mihalynuk 1999, English and Johnston 2005, English et al. 2010).

The geology of northern Cache Creek terrane near Atlin, BC and extending southeast to the Menatatuline Range has been the focus of several studies that are mostly regional in scope (e.g., Aitken 1959, Souther 1971, Monger 1975, Terry 1977, Bloodgood and Bellefontaine 1990, Ash 1994, Mihalynuk et al. 1994). Varied interpretations based on these studies suggest that the Cache Creek terrane in this region comprises several distinct and possibly unrelated components including: an ophiolite and/or rifted arc (e.g., Childe and Thompson 1997, English et al. 2010, Bickerton et al. 2012, Schiarizza 2012), seamounts and/or oceanic plateaus (e.g., English et al. 2010), and a subduction-related accretionary complex (Monger 1975, Terry 1977, Ash 1994, Mihalynuk et al. 1998, English and Johnston 2005).

\section{Geology of the Menatatuline Range area}

The Nahlin ophiolite was first recognized in this region by Aitken (1959). Recent geochronological data indicate a regional age variation of magmatism in the Nahlin ophiolite of 261 to 245 Ma (Figure 1; Table 1). A summary of the geology of the ophiolite is presented 
90 below. Detailed descriptions of all the lithological units within the Menatatuline Range area are

91 presented elsewhere (Zagorevski et al. 2015, 2016a, McGoldrick et al. 2016).

92

\section{Ultramafic rocks in the Nahlin ophiolite}

The best exposures of ultramafic rocks occur in a discontinuous belt from Atlin townsite to Nahlin Mountain about $150 \mathrm{~km}$ southeast (Figure 1). For convenience we herein subdivide the Nahlin ophiolite into the Atlin, Hardluck, and Menatatuline massifs. The Menatatuline massif trends northwest from Nahlin Mountain through the Menatatuline Range (Aitken 1959, Terry 1977). The Hardluck massif trends west-northwest from the Menatatuline (Figure 2; Mihalynuk et al. 2004b).

Ultramafic rocks in both the Hardluck and Menatatuline massifs comprise variably serpentinized harzburgite $(0-50 \%)$ with pyroxenite dikes, and replacive dunite pods (McGoldrick et al. 2016). Massive and layered harzburgite is the dominant lithology and contains $\sim 45-65 \%$ olivine, $\sim 25-40 \%$ orthopyroxene, $3-8 \%$ clinopyroxene, and $<5 \%$ spinel. Layering defined by modal variation of pyroxene is variably developed in both massifs. Lherzolite with up to $15 \%$ emerald-green clinopyroxene occurs in the Hardluck massif (Mihalynuk et al. 2004b). A primary mantle tectonite fabric $\left(S_{1}\right)$ defined by orthopyroxene porphyroclasts is variably developed in both massifs. Pyroxenite dikes $(5-10 \mathrm{~cm}$ wide) are variably abundant. In both the Hardluck and Menatatuline massifs, pyroxenite dikes can be layer-discordant or concordant with respect to the harzburgite layering (Figure 3a). Dikes are locally deformed into meter-scale folds (Figure 3b) and rarely cut folded harzburgite-pyroxenite layering. Discrete dunite pods comprise as much as $20 \%$ of the Menatatuline and Hardluck massifs. The size of individual pods is variable, ranging from sub-metre scale up to $100 \mathrm{~m}$ across. Dunite bodies have sharp contacts against harzburgite, are locally deformed and crosscut 
113 pyroxenite, indicating that there are several generations of these features. The dunite likely

114 represents melt channels formed as a result of melt-rock interaction with the host harzburgite

115 (Kelemen and Dick 1995).

116 Cumulates

117 Mafic-ultramafic cumulates are rare in the Nahlin ophiolite and have only been

118 documented in few localities (Terry 1977, Gabrielse 1998, Mihalynuk et al. 2004b, Zagorevski et

119 al. 2016b). Minor cumulates have been documented in the Hardluck massif northwest of the

120 study area ("Moho Saddle", Figure 1; Mihalynuk et al. 2004b). Pods of pyroxenitic to gabbroic

121 cumulates intrude variably serpentinized harzburgite on the southern margin of the Hardluck

122 massif in the Tseta Creek area (Figure 2). Some pods have highly irregular scalloped margins

123 against the host harzburgite suggesting high temperature, ductile deformation within the

124 lithosphere (Figure 4a). Cumulates include varitextured plagioclase-bearing olivine websterite

125 and gabbronorite, that vary in grain size from fine grained to pegmatitic over meters.

126 Granoblastic textures and primary mineralogy are variably overprinted by green amphibole,

127 chlorite, serpentine, sericite and/or prehnite.

128 Gabbroic rocks

129 Fine grained to pegmatitic gabbros (plagioclase- pyroxene \pm amphibole) intrude the

130 harzburgite tectonite along the southern margin of the Hardluck massif, and throughout the

131 Menatatuline massif. In the Hardluck massif, gabbroic dikes and pods with chilled margins

132 commonly intrude serpentinite, most notably north of the Nahlin fault near Peridotite Peak

133 (Figure 4b). Foliated amphibole- and plagioclase-rich zones are locally present in the gabbro.

134 Gabbro becomes less abundant toward the north, where it typically forms thin dikes \pm sills and

135 reticulated dike and vein swarms within variably serpentinized peridotite. It is unclear whether 
136 these gabbroic intrusions exclusively represent dikes, sills, or a combination of both, as their

137 original orientation within the mantle is ambiguous. Some exposures of gabbro are completely

138 enveloped within fresh peridotite.

Gabbroic dikes \pm sills ranging in width from $<2$ to $20 \mathrm{~m}$ occur as a west- to northtrending swarm crosscutting the Menatatuline massif. Some are undeformed (Figure 4c),

141 whereas others are boudinaged (Figure 4d). Dike cores typically comprise fine to medium

142 grained equigranular plagioclase (40-50\%) and pyroxene (1-3 mm). Many of these dikes display

143 subophitic to intergranular textures, and are variably plagioclase \pm clinopyroxene \pm

144 orthopyroxene-phyric ( $<5 \%, 2-4 \mathrm{~mm}$ phenocrysts). Some dikes have chilled margins against the

145 host harzburgite. Primary mafic mineralogy, including sparse igneous amphibole, is variably

146 altered to lower greenschist facies assemblages of chlorite + epidote \pm actinolite \pm sericite.

147

\section{Nahlin ophiolite volcanic and volcaniclastic rocks}

Volcanic and volcaniclastic rocks are aerially extensive in the northern Cache Creek terrane. Some of these rocks were previously mapped as the Nakina Formation (Monger 1977, Mihalynuk et al. 1996, 2002, English et al. 2002), although this stratigraphic name was originally defined only for Mississippian - Permian volcanic rocks associated with carbonate successions (Monger 1975). Here we avoid this nomenclature to prevent confusion.

Brecciated, massive and rare pillowed flows, with locally pervasive chlorite \pm hematite alteration are exposed northeast of the Menatatuline massif, and between it and Hardluck massif (Figure 2). Younging directions and contact relationships within these sequences are unclear.

The mafic volcanic rocks are plagioclase, clinopyroxene, and orthopyroxene porphyritic. Some plagioclase phenocrysts display sieve textures and growth zoning. Flows are locally highly 
158 vesicular, with calcite \pm chlorite-filled amygdules. Primary mafic minerals are variably altered to

159 chlorite \pm actinolite (clinopyroxene), and to chlorite + calcite \pm epidote \pm sericite (plagioclase).

160 The volcaniclastic rocks comprise mafic crystal and lapilli tuffs that are fine grained,

161 locally vesicular and flow banded. Lapilli and crystal fragments are rounded to subangular, and

162 rarely elongate or shard-like (Figure 5). Crystal fragments comprise plagioclase \pm orthopyroxene

$163 \pm$ clinopyroxene, and one sample contains serpentine pseudomorphs of equant olivine

164 phenocrysts. Lapilli fragments in the pervasively chloritized \pm hematized groundmass preserve

165 volcanic textures, such as intergranular and pseudotrachytic groundmass textures, to varying 166 degrees.

167 Geochemistry

168 Methods

169 Representative samples of all the lithologies described above were selected for

170 lithogeochemical analysis to constrain the petrogenesis of the igneous rocks in the Nahlin

171 ophiolite. The major, minor, and trace element data presented herein are from 28 samples of

172 intrusive and extrusive rocks. A more detailed study of the harzburgite tectonite will be

173 presented elsewhere. Samples were cut into slabs with a rock saw, and were crushed and

174 processed for bulk rock geochemistry at Activation Laboratories in Ancaster, Ontario (Table 2).

175 Major oxides were measured by lithium metaborate/tetreborate fusion and ICP-OES, whereas 176 minor and trace elements were determined by ICP-MS. The suite of standards analysed along 177 with the samples reproduce reported concentrations of major elements to within $9 \%$, large-ion 178 lithophile elements (LILE) to within 13\%, high-field strength elements (HFSE) to within 9\%, 179 and rare-earth elements (REE) to within 7\% (Table 2). 
180

181

182

183

184

185

186

187

188

189

190

191

192

193

194

195

196

197

198

199

200

201

202

\section{Element Mobility}

All the samples have experienced up to greenschist facies metamorphism, which can result in element mobility. Elements such as $\mathrm{Ti}, \mathrm{Zr}, \mathrm{Hf}, \mathrm{Nb}$, and $\mathrm{Ta}$, and the REE have been shown to be relatively immobile during hydrothermal alteration and up to greenschist facies metamorphism (MacLean 1990, Jenner 1996, Pearce 1996). Using discriminant diagrams involving the immobile elements $\mathrm{Nb}, \mathrm{Y}, \mathrm{Zr}$ and $\mathrm{Ti}$, the vast majority of the intrusive, volcanic, and volcaniclastic samples of the Menatatuline Range area classify as subalkaline, and basaltic to basaltic andesite (Figure 6a). An identical result is obtained for these rocks using the more traditional alkalies-silica classification scheme (Figure 6b), showing $\mathrm{Na}$ and $\mathrm{K}$ have not been compromised by metamorphism. Molecular proportion diagrams (Figure 7), which compare the composition of the whole rocks with the stoichiometry of minerals involved in their differentiation, suggest that most major elements $(\mathrm{Na}, \mathrm{K}, \mathrm{Si}, \mathrm{Mg}, \mathrm{Fe}, \mathrm{Ca})$ were largely unaffected by metamorphism. For example, with the exception of two samples, the gabbros, dikes and mafic volcanic rocks lie along tielines between plagioclase, clinopyroxene and olivine components (Figure 7), a trend that is predicted during low-pressure crystallization of basaltic magma.

\section{Basalts and gabbro dikes}

Most of the basalts and gabbros of the Menatatuline Range area are subalkaline and basaltic in terms of major and trace elements (Figure 6). These rocks lie along differentiation trends consistent with accumulation or removal of plagioclase and clinopyroxene (CPX $\mathrm{CaMgSi}_{2} \mathrm{O}_{6}, \mathrm{CaTs}-\mathrm{CaAl}_{2} \mathrm{SiO}_{6}$ ), as observed petrographically in the rocks (Figure 7). Many of the samples are similar to the reference N-MORB composition (grey triangle, Figure 6a), and major and trace element data indicate that these rocks are predominantly tholeiitic (Figure 6, 8).

Ratios of $\mathrm{Nb} / \mathrm{Yb}$ indicate that the volcanic and plutonic samples from the Nahlin ophiolite plot 
203

204

205

206

207

near reference values for N-MORB (Figure 9), suggesting derivation from a depleted source.

However, many of the Nahlin ophiolite rocks also show variable enrichment of $\mathrm{Th} / \mathrm{Nb}$ over $\mathrm{N}-$ MORB, and plot along the subduction enrichment trend. On N-MORB normalized trace element plots, the volcanic and plutonic rocks of the Nahlin ophiolite have similar flat trace element profiles displaying consistent negative Nb-anomaly (Figure 10).

A narrow unit of distinctly more enriched volcanic rocks also occurs in the Menatatuline Range area (Figure 2). These are subalkaline basalts with higher $\mathrm{Nb} / \mathrm{Y}$ ratios than the majority of the volcanic rocks of the ophiolite and close to the reference value for E-MORB (Figure $6 \mathbf{b}$; Sun and McDonough 1989). Trace element data indicate that these volcanic rocks are tholeiitic to transitional (Figure 8). Other trace element ratios indicate that these samples have E-MORBlike chemistry, and plot along the source enrichment trend between reference compositions for N-MORB (depleted source) and OIB (enriched source) (Figure 9). The E-MORB-like volcanic rocks lack the subduction enrichment of $\mathrm{Th} / \mathrm{Nb}$ recorded in the volcanic rocks of the ophiolite (Figure 9). Multi-element diagrams highlight the enrichment of LREE over HREE, and lack of Th-Nb and Ti anomalies in these samples (Figure 10).

A series highly vesicular basalts are petrographically and geochemically distinct from the other basalts of the ophiolite in the field. These rocks contain serpentine pseudomorphs after subhedral to euhedral 0.5 to $1 \mathrm{~mm}$ olivine phenocrysts, sparse subhedral to euhedral $1-4 \mathrm{~mm}$ plagioclase phenocrysts which are variably altered to sericite + calcite, and up to $30 \%$ calcitefilled amygdules that are typically $1 \mathrm{~mm}$ in diameter. These highly vesicular basalts plot along an olivine control line (Figure 7ab) consistent with olivine accumulation observed petrographically. Two samples of these mafic volcanic rocks lack $\mathrm{Nb}$ anomalies, have significant enrichment in 
225

226

227

228

229

230

231

232

233

234

235

236

237

238

239

240

241

242

243

244

245

246

LREE over HREE, and Nb/Y typical of alkali basalts (Figures 6, 9, and 10) such as typical ocean island basalt (OIB; Sun and McDonough 1989).

\section{Ultramafic and mafic cumulates}

The major element composition of the cumulates lie along tielines between either olivine, clinopyroxene or plagioclase - all phases observed to vary modally in these rocks (Figure 7).

Some of the trace element diagrams employed above to characterize the volcanic and plutonic rocks are inappropriate for cumulates (Langmuir 1989, Bédard 1994, Pearce 1996). Multi-

element plots, however, can still be useful in the petrogenetic interpretation of these non-liquidus compositions (Bédard 1994). The plagioclase-bearing olivine websterite and gabbronorite cumulates have flat trace element profiles nearly an order of magnitude more depleted than the other intrusive rocks of the ophiolite (Figure 10). The plagioclase-bearing olivine websterite has a pronounced negative Eu anomaly, whereas the gabbroic cumulates show slight positive Eu anomalies, reflecting variable fractionation and accumulation of plagioclase. All the cumulate samples are enriched in $\mathrm{Th} \pm \mathrm{Nb}$ relative to the $\mathrm{REE}$, but lack the negative $\mathrm{Nb}$ anomalies characteristic of other plutonic rocks of the ophiolite (Figure 10).

\section{Discussion}

\section{Stratigraphy and structure of the Nahlin ophiolite}

The Nahlin ophiolite contains some components of the classic Penrose-style ophiolite (Anonymous 1972), and though some primary contact relations may be obscured by faulting, it is still possible to constrain the stratigraphy of the ophiolite (Figure 11). The harzburgite massifs at the base of the Nahlin ophiolite are interpreted as mantle lithosphere and are locally crosscut by multiple generations of gabbroic dikes, some of which are unstrained (Figure 4c) whereas 
247 others have been boudinaged within the mantle (Figure 4d). Lower crustal cumulates and

248 sheeted dike complexes are volumetrically minor in the Nahlin ophiolite. Locally, gabbroic dike-

249 and-sill complexes extensively intrude the mantle rocks. These melt conduits presumably fed

250 volcanic flows at the surface, which are represented by the aerially-extensive basalt and related

251 mafic volcaniclastic rocks in the Menatatuline Range area (in part formerly mapped as Nakina

252 Formation). Some of these massive mafic rocks have previously been mapped as volcanic flows,

253 even where they lack any extrusive textures (Gabrielse 1998, Mihalynuk 1999, Mihalynuk et al.

254 2003) but are now recognized as hypabyssal dike-and-sill and sill-sediment complexes

255 (Zagorevski et al. 2016a).

Constraining the stratigraphic way-up in the Nahlin ophiolite is not everywhere

257 straightforward. A section through the uppermost mantle and into the lowermost crust is exposed

258 at the "Moho Saddle" (Figure 2) to the northwest of Peridotite Peak, and indicates that the

259 ophiolite youngs towards the south (Mihalynuk et al. 2004b). The presence of rare pyroxenitic

260 and gabbroic cumulates exclusively on the southern side of the Hardluck massif supports this

261 interpretation. Elsewhere in the Nahlin ophiolite, however, the harzburgite massifs are fault-

262 bound, leaving little evidence as to the way-up in stratigraphy. These fault-bound sections of

263 mantle harzburgite tectonite are often juxtaposed against basalt or chert. A possible interpretation

264 for this juxtaposition and the locally missing lower crustal section, is that the Nahlin ophiolite

265 represents an intraoceanic core complex (Zagorevski et al. 2015). Similar to other fossil oceanic

266 core complexes recognized in the rock record (e.g., Ohara et al. 2003, Maffione et al. 2013,

267 Lagabrielle et al. 2015), the spinel-facies harzburgite tectonite may have been exhumed along a

268 low angle normal fault to shallow depths (plagioclase stability zone), where it acted as a rigid

269 body during the intrusion of later gabbroic dikes. 


\section{Tectonic setting of the Nahlin ophiolite}

The reconstructed stratigraphy of the Nahlin ophiolite based on recent field work in the northern Cache Creek terrane can be corroborated using lithogeochemical data. The gabbro and diabase dikes that crosscut the mantle sections of the Nahlin ophiolite have arc tholeiitic chemistry, and REE profiles identical to those of spatially associated basalt and mafic volcaniclastic rocks (Figure 10). The flat to low positive slope of the REE profiles (Figure 12), and the low $\mathrm{Nb} / \mathrm{Yb}$ ratios, indicate derivation from a LREE-depleted mantle source that experienced earlier melt extraction (Jenner 1996, Pearce 1996). The intrusive and extrusive rocks are enriched in $\mathrm{Th} / \mathrm{Yb}$ over typical N-MORB values (Figure 9), suggesting that subductionrelated fluids played a role in the genesis of the ophiolite crust. All of the plutonic and volcanic rocks display a negative Th-Nb-La anomaly (Figure 10) and enrichment of LILE over HFSE. These characteristics are generally considered a subduction zone signature similar to that of island arc tholeiites (IAT), and are linked to relative contributions of these elements from the subducting slab to the source of the arc magmas (Pearce and Norry 1979, Saunders et al. 1988, Pearce and Peate 1995, Jenner 1996, Pearce 1996). The remarkably consistent arc tholeiite chemistry, subduction-related enrichment, and the crosscutting relationships linking the gabbroic rocks to the mantle suggest that the Hardluck and Menatatuline massifs are part of a suprasubduction zone (SSZ) ophiolite.

Rare earth element profiles of the extrusive igneous rocks in the Nahlin ophiolite can be compared to melt compositions produced by fractional melting of peridotite, to constrain the degree of melting required to generate the crust of the Nahlin ophiolite. Melting models employed in this study follow the methodology of Warren (2016), in which a depleted MORB mantle (DMM) source (Workman and Hart 2005) undergoes non-modal fractional melting in the 
293 spinel stability field according to the melting reaction $0.56 \mathrm{Opx}+0.72 \mathrm{Cpx}+0.04 \mathrm{Sp}=0.34 \mathrm{Ol}$

$294+1.0$ Melt (Wasylenki et al. 2003). Partition coefficients melt for the REE are after Sun and

295 Liang (2014) and Warren (2016), and are calculated assuming a mantle of DMM composition at

296 a potential temperature of $1300^{\circ} \mathrm{C}$. The range of REE profiles of the Nahlin ophiolite basaltic

297 rocks is reproduced by 2 to $20 \%$ non-modal fractional melting (Figure 12). This suggests that

298 some of the volcanic rocks represent erupted products of low degrees of partial melting, whereas

299 others result from combined segregated melts of up to $20 \%$ melting. Considering the range of

$300 \mathrm{MgO}$ values ( 4 to 9 wt \%; Table 2), we assume that most of these volcanic rocks do not

301 represent primary or primitive melts (Niu and Batiza 1991, Kinzler and Grove 1992). The REE

302 in basalt will increase in abundance with crystal fractionation of early olivine. In this way the

303 concentrations of REE in Nahlin arc tholeiites are higher than in their original primitive parental

304 melts, requiring that our melt fraction estimates are minima.

The mantle melting model described above also provides a residual mantle composition, which can be compared to peridotites of the Nahlin ophiolite. Whole-rock REE data from

307 peridotite samples near the "Moho Saddle", Peridotite Peak, and Peridotite Peak East (Babechuk

308 et al. 2010) require 10 to $20 \%$ partial melting to reproduce measured HREE concentrations

309 (Figure 12). Light REE enrichment of the Nahlin peridotites is not predicted by the modeled

310 residue compositions, but may be related to cryptic mantle metasomatism or refertilization that is

311 observed in many abyssal and ophiolite peridotites (e.g., Bizimis et al. 2000, Warren and

312 Shimizu 2010, Uysal et al. 2016). The range of melt depletion recorded in the peridotites (10-

$31320 \%$ ) overlaps with the melt estimates necessary to generate the basaltic rocks of the Nahlin

314 ophiolite $(2-20 \%)$. This indicates that the arc tholeiite intrusive and extrusive igneous rocks in

315 the Menatatuline Range area are demonstrably the products of the Nahlin harzburgites with 
316

317

318

319

320

321

322

323

324

325

326

327

328

329

330

331

332

333

334

335

336

337

338

which they are spatially associated. Alternatively, the arc tholeiite magmatism in the Nahlin ophiolite was established on mantle lithosphere that experienced previous history of arc magmatism. Geochronological constraints on the timing of volcanism are needed to discriminate between these hypotheses. Regardless, the mantle harzburgites of the Nahlin ophiolite are thus not related to the OIB and E-MORB sequences.

\section{Connection to other Cache Creek assemblages}

Tholeiitic plutonic and volcanic rocks of the Nahlin ophiolite display a predominantly arc-backarc geochemical signature. A similar arc-backarc setting has been inferred along-strike to the north in the Nakina area (English et al. 2010), and to the south in the Kutcho assemblage (Childe and Thompson 1997, Mihalynuk and Cordey 1997) (Figure 1). The oceanic crustal assemblage in the Nakina area (Figure 1) (English et al. (2010) comprises Middle to Late Permian intrusive and extrusive igneous rocks of variable affinity (e.g., IAT, backarc basin basalt (BABB), calc-alkaline) that formed from a depleted N-MORB-like source in an arc or backarc setting (Devine 2002, English et al. 2010). As these rocks are physically continuous with and chemically similar to those in the Nahlin area, they could form part of the same arc-backarc system as the Nahlin ophiolite (Figure 10).

The Early to Middle Triassic Kutcho arc exposed near Dease Lake (Figure 1) was previously correlated with the Nakina area (English and Johnston 2005, English et al. 2010). The Kutcho assemblage is characterized by bimodal tholeiitic volcanic and volcaniclastic rocks that formed in a intra-oceanic arc (ca. 254-242 Ma: (Barrett et al. 1996, Childe and Thompson 1997, Barrett and MacLean 1999, Schiarizza 2012). The Kutcho assemblage and the Nahlin ophiolite likely represent different segments of the same, extensional Late Permian to Middle Triassic arcbackarc system, similar to the modern Izu-Bonin-Mariana or Tonga-Tofua-Kermadec arcs 
339 (Reagan et al. 2010, 2013, Ishizuka et al. 2011 ; Smith and Price 2006)). In such analogues, the

340 Nahlin ophiolite could represent more advanced stages of rifting, similar to the Lau and Parece-

341 Vela basins, whereas the Kutcho assemblage either represents an incipient rift or highly extended

$342 \operatorname{arc}$ (e.g., southern termination of west Mariana Trough or parts of the of the Lau basin).

Alternatively, the Kutcho assemblage and Nahlin ophiolite may represent along strike

344 variations in magmatic versus tectonic-accommodated extension in the backarc region, and in the nature of the slab derived components added to the mantle wedge as described in the southern Havre Trough (Wysoczanski et al. 2010, Todd et al. 2011). This configuration reflects

347 anomalous thermal regimes in the mantle wedge ("hot fingers", Tamura et al. 2002, Todd et al.

348 2011) which result in cross-arc chains of constructive volcanic centres separated by basinal 'rift

349 regimes' in which BABB are erupted (Wysoczanski et al. 2010). Application of such a setting to 350 the northern Cache Creek composite terrane can explain the apparent lack of a mature Permo351 Triassic arc spatially associated with the Nahlin ophiolite (Figure 13).

Alternatively, the Nahlin ophiolite may have formed in a proto-forearc setting associated with subduction initiation. Similar to the proposed origin of the Izu-Bonin-Mariana arc,

354 nucleation of a new intraoceanic subduction zone may have been accompanied by seafloor 355 spreading in what would become the forearc region (Figure 13; Stern et al. 2012, Maffione et al. 356 2015). A progressive change in volcanic chemistry from initial forearc spreading to development 357 of a mature arc follows from the evolution of tholeiitic MORB-like volcanic rocks (forearc 358 basalts) at the base to volcanic arc-like basalts including boninites at the top of the volcanic 359 sequence in the forearc (Reagan et al. 2010, 2013, Ishizuka et al. 2011, Stern et al. 2012). This 360 chemostratigraphy is recognized in other SSZ ophiolites (Mirdita and Pindos ophiolites -

361 (Saccani and Photiades 2004, Dilek et al. 2008, Whattam and Stern 2011), but is not recognized 
362 in the Nahlin ophiolite, perhaps due to structural dismemberment. A subduction initiation origin

363 may also account for the lack of a preserved arc associated with the Nahlin ophiolite, as a newly

364 nucleated convergent margin may be short-lived and need not develop a mature arc (Whattam

365 and Stern 2011).

\section{The relevance of $O I B$ and $E-M O R B$}

The two E-MORB-type volcanic rocks in the Menatatuline Range area define a thin belt

368 along the contact of the volcanic rocks of the ophiolite and the Kedahda Formation (Figure 2).

369 Enriched MORB-like basalts have been described to the north in the Nakina area (English et al.

370 2010). These volcanic rocks require an enriched non-arc source indicating that these rocks

371 cannot be directly related to the arc tholeiites of the Nahlin ophiolite. The volumetrically minor

372 E-MORB magmatism could represent continued spreading in the backarc environment and

373 tapping of a more enriched mantle source or it may reflect a heterogeneous mantle source that

374 includes both depleted and enriched components (e.g., Pomonis et al. 2006, Dilek and Furnes

375 2009, Gale et al. 2013, Wilson et al. 2013). Alternatively, the E-MORB-type volcanic rocks may

376 be unrelated to the ophiolite. The complete lack of any subduction zone signature, and the

377 proximity of these basalts to a fault imbricated package of siliciclastic, chert and carbonate rocks,

378 may indicate that the E-MORB-type samples are a part of the Tethyan carbonate successions.

Non-arc magmatism is well-documented elsewhere in the northern Cache Creek terrane.

380 For example, the Teslin Formation limestone with its Permian Tethyan fauna is stratigraphically

381 intercalated with French Range Formation E-MORB-type basalt and related felsic volcanic rocks

382 which yielded a ca. 263 Ma U-Pb zircon crystallization age (Monger 1975, Mihalynuk and

383 Cordey 1997, English et al. 2010). Permian Teslin Formation limestone in the Hall Lake area is

384 also intercalated with OIB (Monger 1975, Mihalynuk and Cordey 1997). Carboniferous OIB and 
385 386

related rhyolite is also known to occur within the Horsefeed Formation limestone (Devine 2002, Merran 2002).

The intraplate (OIB) volcanic rocks and their associated carbonate platforms have been proposed to represent fragments of exotic oceanic plateaux or seamounts (Monger 1975, English et al. 2010). These successions were likely sheared off the down-going plate and accreted to the Late Permian to Early Triassic arc which is, in part, represented by the Nahlin ophiolite (c.f. English et al. 2010). Incorporation of the E-MORB-OIB-carbonate platform sequences in to the subduction channel is supported by local preservation of blueschist-facies metamorphism in the French Range Formation (Mihalynuk et al. 1998).

\section{Significance to Cordilleran tectonic models}

Field and lithogeochemical data indicate that mantle, lower crustal and supracrustal rocks of the Nahlin ophiolite formed within a Permo-Triassic arc system. Rocks of the ophiolite in northern Cache Creek terrane were previously grouped with the intraplate volcanic rocks,and Tethyan carbonate successions, as part of the subducting slab of the Cache Creek ocean basin (e.g., Ash, 1994; Monger 1975, 1977, Mihalynuk et al. 1992, 1994, 1999, 2004a, Nelson and Colpron 2007). But the preservation potential of large tracts of ophiolite that forms part of the subducting plate is poor, because subducting lithosphere lacks the buoyancy to cause orogenesis (Cloos 1993). Furthermore, the accreted ophiolites are typically small and lack lower crust and mantle sections (Kimura and Ludden 1995, Zagorevski et al. 2009, Zagorevski and van Staal 2011). In contrast, the herein proposed arc-backarc setting of the Nahlin ophiolite has a greater preservation potential and is consistent with the occurrence of an extensive mantle section, which is characteristic of obducted ophiolites (Zagorevski and van Staal 2011). The Nahlin ophiolite thus represents the upper plate at an intraoceanic convergent margin. The structurally-imbricated 
408

409

410

Mississippian to Permian limestone, alkaline volcanic rocks and chert, including those that are characterized by Tethyan fauna, must represent part of the subducting ocean basin. This view is supported by preservation of blueschist in the nearby French Range (Mihalynuk et al. 1998).

The regional map patterns in the northern Cache Creek composite terrane are complicated by overprinting by deformation episodes including poorly exposed obduction structures, Jurassic E-W trending folds and thrust faults, and northwest trending Cretaceous strike-slip faults. The ophiolite is generally exposed to the southwest of the 'Cache Creek Complex' (the subduction accretionary complex including OIB-carbonate successions, English et al. 2010). This distribution suggests that the ophiolite was obducted along northeast-vergent structures over a southwest dipping intraoceanic subduction zone (cf. English et al 2010).

Nonetheless, the upper and lower plate domains we identify herein (Figure 11) represent fundamentally different associations of rocks, and therefore meet the definition of two separate "terranes" : fault-bound areas possessing unique tectonic assemblages that differ from those of adjacent terranes (Gabrielse et al. 1991). The true terrane-bounding fault in the northern Cache Creek terrane is not, therefore, the Nahlin fault Figure 1), but rather the suture between the upper and lower plate assemblages, where it is exposed. Contrary to the current terrane boundaries, this suture cannot be neatly drawn as an orogen near-parallel fault, but its approximate equivalents can be observed in outcrop. At Mount Nimbus (Figure 1), for example, ophiolite is thrust over Mississippian carbonate successions bearing OIB-type volcanic rocks (Zagorevski et al. 2016a).

The proposed separation of the composite Cache Creek terrane into arc and seamount terranes has significant implications for the interpretation of oceanic terranes in the Cordillera, including the Cache Creek composite terrane further south, where grouping of overriding and 
431 subducting plates into a single terrane results in significant misadventure. For example, the

432 presence of OIB, E-MORB and N-MORB-like basalts in the Cache Creek terrane near Fort St.

433 James led to a suggestion for its formation in a ridge-centered or near-ridge oceanic island

434 plateau environment (Tardy et al. 2001, Lapierre et al. 2003). Some of the Cache Creek MORB-

435 like samples of Lapierre et al. (2003; Type 1 N-MORB) actually show significant negative $\mathrm{Nb}$

436 anomalies indicating that these samples are likely island arc tholeiites and are not related to

437 alkaline lavas at all. Their association with gabbroic and harzburgitic rocks suggest that, together

438 with the mantle harzburgite, the basalts are correlative to the Nahlin ophiolite, consistent with

439 their inferred age (ca. 257 Ma; Struik et al. 2001). These rocks also lie adjacent to the Sitlika

440 Assemblage (Childe and Schiarizza 1997), a correlative of the Kutcho Assemblage. Following

441 our proposed tectono-stratigraphic relationships for the northern Cache Creek terrane, the

442 alkaline and E-MORB volcanic rocks and associated carbonates in Fort St. James area form part

443 of the lower, partly subducted plate onto which the Trembleur ophiolite and Kutcho - Sitlika arc

444 rocks were obducted.

\section{Conclusions}

446 Intrusive and extrusive igneous rocks of the Nahlin ophiolite in the northern Cache Creek

447 composite terrane are dominantly subalkaline and of arc-affinity. The arc tholeiites represent the

448 products of up to $20 \%$ partial melting, and are the melt complement to similar levels of melting

449 recorded by harzburgite residues in the mantle section of the ophiolite. The volcanic rocks of the

450 Nahlin ophiolite are likely correlative to the nearby subalkaline volcanic rocks in the Nakina

451 transect and Kutcho assemblage, and may be linked to a regionally extensive Permo-Triassic

452 intraoceanic arc. During the amalgamation of the composite Cache Creek terrane, this arc

453 occupied the upper plate thereby facilitating the preservation of extensive fragments of oceanic 
454 lithospheric mantle. The volumetrically minor OIB-type volcanic rocks associated with Tethyan

455 fauna-bearing carbonate successions represent fragments of oceanic plateaux and their carbonate 456 atolls sliced off of the subducting plate and incorporated into a subduction accretionary complex.

457 These sequences are older than and petrogenetically unrelated to the Nahlin ophiolite. This

458 configuration challenges some accepted models for the Cache Creek terrane and the terrane-

459 bounding Nahlin fault. A re-evaluation of terrane-bounding structures in this light is paramount

460 to a better understanding of the assembly and displacement of terranes in the northern Cordillera.

461 Acknowledgments

462 The authors thank N. Graham and P. Vera at Discovery Helicopters Ltd. Atlin B.C. for reliable

463 transport. We are grateful to R. Maxeiner and R. Stern for their reviews. This research was

464 supported by the Geological Survey of Canada's Geomapping for Energy and Minerals program

465 (GEM2-Cordillera), Natural Sciences and Engineering Research Council of Canada (NSERC)

466 and Geoscience BC scholarships (S. McGoldrick), and NSERC Discovery grant (D. Canil). 


\section{Figure Captions}

470

471

472

473

474

475

476

477

478

479

480

481

482

483

484

485

486

487

488

489

490

Figure 1: Lower inset map shows terranes of northern British Columbia and Yukon highlighting the Cache Creek terrane ( $\mathrm{CC}$; yellow) and location of the Menatatuline Range study area (red star). Main panel shows the regional geology of the northern Cache Creek composite terrane in Yukon and British Columbia. The Menatatuline Range study area is outlined in red dashed lines. Other localities referenced in text include: Nakina transect (NK, black dashed box), Hall Lake (HL), "Moho Saddle" (MS), Mount Nimbus (MN), French Range (FR), and the Kutcho assemblage (KT). Diamonds refer to locations of geochronological data in Table 1. Inset map modified after Nelson and Colpron (2011). Main panel map modified after Zagorevski et al. (2015).

Figure 2: Bedrock geology of the Menatatuline Range area, from Peridotite Peak to Nahlin Mountain, based on 2015 - 2016 mapping and compiled from previous data of Mihalynuk et al. (1996). Sample locations symbolized by lithology and chemical affinity as discussed in text.

Names of geological features referenced in text are in italic font (e.g. Nahlin fault). Informal place names are indicated by quotation marks (e.g., "Tseta Creek area”). Background topographic raster image from Natural Resources Canada (1990a, 1990b).

Figure 3: Field pictures of ultramafic rocks of the Nahlin ophiolite. (A) Primary tectonic fabric $\left(\mathrm{S}_{1}\right)$, and pyroxenite dike transposed into $\mathrm{S}_{1}$, in harzburgite tectonite truncated by a replacive dunite pod on Peridotite Peak. (B) Tight, near isoclinal folding of a pyroxenite dike in harzburgite tectonite on Peridotite Peak.

Figure 4: Field images of intrusive rocks of the Nahlin ophiolite in the Menatatuline Range area. (A) Boudinaged altered ultramafic cumulate (pale) with scalloped margins surrounded by 
491 harzburgite (dun brown), on the southern side of the Hardluck massif. (B) Varitextured gabbro

492 intrusion on the southern side of the Hardluck massif. Grain size within the gabbroic intrusions

493 can vary from fine grained (top) to pegmatitic (bottom) for the sample shown. (C) Planar

494 margins (white dashed lines) of a gabbroic dike intruding harzburgite at Nahlin Mountain. (D)

495 Boudinaged gabbroic dikes protruding along the slopes of Nahlin Mountain among recessively

496 weathering serpentinite scree.

497 Figure 5: Images of mafic volcanic rocks previously grouped as part of the Nakina Formation, in 498 northwestern British Columbia. (A) Locally fragmental texture in pervasively hematized

499 volcaniclastic rocks. (B) Photomicrograph of an ultramafic crystal tuff with orthopyroxene

500 crystal fragments, and serpentine pseudomorphs after rounded olivine fragments in PPL, and (C)

501 in XPL. (D) Photomicrograph of a mafic tuff with lapilli in PPL, and (E) in XPL.

502 Figure 6: Igneous rock discrimination diagrams using (A) trace element ratios (Pearce 1996) and

503 (B) $\mathrm{SiO}_{2}$ versus total alkalis (Le Maitre 1989). The mafic volcanic rocks, gabbros, and gabbroic

504 dikes of the Nahlin ophiolite are all subalkaline and basaltic to andesitic in composition, with

505 the exception of one gabbro, which may have experienced enrichment in alkalis. One of the

506 alkali basalts (blue circles) plots within the subalkaline basalt field, suggesting it may have

507 experienced variable degrees of silicification and/or alkali loss. Reference composition for

508 normal mid-ocean ridge basalt (N-MORB), enriched mid-ocean ridge basalt (E-MORB), and

509 ocean island basalt (OIB) shown in grey symbols for comparison (Sun and McDonough 1989).

510 Data from igneous rocks of the Nakina transect shown for comparison (black crosses; English et

511 al. 2010). 
512 Figure 7: Covariation of molar (a) $\mathrm{Na}+\mathrm{K}$, (b) $\mathrm{Ca}+\mathrm{Na}$ and (c) $\mathrm{Mg}+\mathrm{Fe}$ with $\mathrm{Si}+\mathrm{Al}$ in the intrusive

513 and extrusive rocks of the Menatatuline range area (this study) as well as other literature data for

514 the Nakina region in northern Cache Creek terrane (English et al, 2010). Plotting in molar space

515 shows the mineral stoichiometric control on bulk rock compositions. Note the trend of the

516 intrusive and extrusive mafic rocks along control lines (dashed) between clinopyroxene

517 components (CPX, CaTs) and plagioclase (PL), and of the olvine-phyric alkali basalts and

518 cumulate rocks toward olivine (OL). CPX, clinopyroxene; CaTs - Ca-tschermaks pyroxene; OL,

519 olivine; PL, plagioclase.

520 Figure 8: Discrimination of magma series by trace element data following the method of Ross

521 and Bédard (2009). The rocks of the ophiolite are predominantly tholeiitic. Volcanic rocks from

522 the southern Cache Creek terrane shown for comparison with northern Cache Creek data (black

523 "x" symbols; Tardy et al. 2001, Lapierre et al. 2003). All other symbols as in Figure 6.

524 Figure 9: Lithogeochemical data for samples from the northern Cache Creek terrane plotted in

$525 \mathrm{Nb} / \mathrm{Yb}-\mathrm{Th} / \mathrm{Yb}$ space. Reference compositions for N-MORB, E-MORB, and OIB are shown for 526 comparison (grey symbols; Sun and McDonough 1989). Samples derived from an enriched

527 source plot near the OIB reference point with high $\mathrm{Th} / \mathrm{Yb}$ and $\mathrm{Nb} / \mathrm{Yb}$ ratios. The majority of the

528 Nahlin ophiolite samples of both plutonic and volcanic rocks plot near the N-MORB reference

529 value, but show evidence of subduction-related enrichment. Data from the Nakina Transect

530 (English et al. 2010), and from volcanic rocks in the southern Cache Creek terrane in central BC

531 (Tardy et al. 2001, Lapierre et al. 2003) are shown for comparison. Samples from the southern

532 Cache Creek plot along the source enrichment trend, and appear to lack any subduction

533 enrichment. Modified after Pearce (1982), and English et al. (2010). 
534 Figure 10: Rare-earth element (REE) multi-element concentrations relative to N-MORB (Sun 535 and McDonough 1989) for intrusive and extrusive igneous rocks of the Menatatuline Range area. 536 (A) Volcanic and volcaniclastic rocks of the Nahlin ophiolite (green triangles) compared to the 537 range of compositions of island-arc tholeiites (IAT) and backarc basin basalts (BABB) in the 538 Nakina transect, and to mafic volcanic rocks from the Kutcho assemblage (white triangles, 539 Childe and Thompson 1997). (B) Two E-MORB-type (red triangles) and two OIB-type (blue 540 circles) volcanic rocks from the Menatatuline Range area, compared to the range of compositions 541 of E-MORB and OIB volcanic rocks in the Nakina transect. (C) Gabbroic rocks of the Nahlin 542 ophiolite, including dikes \pm sills (blue squares) and gabbro pods (red circles). Data from Nakina 543 transect gabbros shown by the grey shaded region. (D) Ultramafic and gabbroic cumulates from 544 the Nahlin ophiolite. All data for the Nakina transect (shaded regions) from English et al. (2010).

545 Figure 11: Schematic stratigraphic columns for the upper plate, lower plate, and overlap 546 assemblages of the northern Cache Creek terrane based on new and existing geochronological 547 data. Age constraints for lower plate sedimentary rocks after Monger $(1975,1977)$, Cordey et al. 548 (1991), and Mihalynuk et al. (2003, 2004b). Age constraints for the overlap assemblage 549 sedimentary rocks after Cordey et al. (1991), and Mihalynuk et al. (2003, 2004b), and for the 550 upper plate (ophiolite) assemblage after Gordey et al. (1998), Devine (2002), Mihalynuk et al. 551 (2004b), Zagorevski (2016), and Zagorevski et al. (2016a, 2017).

552 Figure 12: (A) Volcanic rock compositions of the Nahlin ophiolite (grey triangles; this study) 553 and correlative Nakina transect BABB and IAT compositions (light and dark grey shaded areas; 554 English et al. 2010) compared to partial melting models. Dot-dashed black line indicates the 555 bulk-peridotite starting composition, and coloured dashed lines reflect segregated melt 556 compositions after $1-20 \%$ non-modal fractional partial melting of a DMM source in the spinel 
557 stability field. All results normalized to chondrite. (B) Bulk-rock REE concentrations for

558 peridotite samples from nearby Peridotite Peak, "Moho Saddle", and Peridotite Peak East (grey

559 circles; Babechuk et al 2010) compared to modeled residue compositions after depletion by 1 -

$56020 \%$ non-modal fractional partial melting of a DMM source in the spinel stability field. All

561 model parameters for (A) and (B) follow those of Warren (2016). Starting bulk-rock composition

562 for DMM is after Workman and Hart (2005), with partition coefficients calculated for a mantle

563 of DMM composition at a potential temperature of $130{ }^{\circ} \mathrm{C}$ (Sun and Liang 2014, Warren 2016).

564 Melting follows the reaction of Wasylenki et al. (2003) for DMM1 composition at 1.0 GPa : 0.56

565 Opx $+0.72 \mathrm{Cpx}+0.04 \mathrm{Sp}=0.34 \mathrm{Ol}+1.0$ Melt.

566 Figure 13: Potential configurations of the lower plate OIB-carbonate assemblage and the Nahlin 567 ophiolite during the formation of the Nahlin ophiolite as a result of subduction initiation (A, B

568 and C; modified after Maffione et al. 2015), or during spreading in a backarc setting (D) and in a

569 southern Havre Trough-like setting (E). (A) Progressive development of a new subduction zone

570 parallel to a paleo-spreading centre or other pre-existing plane of weakness in the oceanic crust.

571 In response to far-field ridge-perpendicular compression, deformation is localized along a pre-

572 existing detachment fault and an underthrust develops. (B) The underthrust propagates laterally,

573 nucleating a new subduction zone. Fluids are released from the subducting plate. (C) Extension

574 on the overriding plate triggers renewed magmatism along the paleo-spreading centre, thereby

575 forming new SSZ-type crust, preserved in what may later become the forearc region of a mature

576 arc, and thus propensity to be preserved as a SSZ-type ophiolite. (D) Plate configuration for

577 development of the Nahlin ophiolite along a backarc spreading centre. Combination of

578 decompression (dry) and flux melting reconciles the back arc chemistry of the volcanic rocks of

579 the Nahlin ophiolite. (E) Formation of the Nahlin ophiolite in a southern Havre Trough-like 
580 setting, where cross-arc chains of volcanic centres are separated by zone of tectonically

581 accommodated extension erupting back arc basalt along basinal rifts (Wysoczanski et al. 2010).

582 Along-strike variations in volcanic chemistry, from volcanic arc basalts (e.g., Kutcho arc

583 assemblage) to back arc basalt (e.g., arc tholeiites of the Nahlin ophiolite), may explain the lack

584 of preserved arc in the immediate vicinity of the Nahlin ophiolite.

585 Table 1: Summary of geochronological data constraining the timing of magmatism related to

586 Permo-Triassic arc activity, including evolution of the Nahlin ophiolite, in the northern Cache

587 Creek composite terrane.

588 Table 2: Lithogeochemical data from plutonic and volcanic rocks of the Menatatuline Range 589 area (n.d. indicates no data). 
591

592

593

594

595

596

597

598

599

600

601

602

603

604

605

606

607

608

609

610

611

612

613

\section{References}

Aitken, J.D. 1959. Atlin map-area, British Columbia (104 N). Geological Survey of Canada Memoir, 307: 1-89.

Anonymous. 1972. Penrose conference on ophiolites. In Geotimes. pp. 22-24.

Ash, C.H. 1994. Origin and tectonic setting of ophiolitic ultramafic rocks in the Atlin area, British Columbia (NTS 104N). In Bulletin 94. British Columbia Geological Survey.

Ash, C.H., and Arksey, R.L. 1990. The Atlin ultramafic allochthon: ophiolitic basement within the Cache Creek terrane; tectonic and metallogenic significance. Geological Fieldwork 1989,: 365-374.

Babechuk, M.G., Kamber, B.S., Greig, A., Canil, D., and Kodolányi, J. 2010. The behaviour of tungsten during mantle melting revisited with implications for planetary differentiation time scales. Geochimica et Cosmochimica Acta, 74: 1448-1470. doi:10.1016/j.gca.2009.11.018.

Barrett, T.J., and MacLean, W.H. 1999. Volcanic sequences, lithogeochemistry, and hydrothermal alteration in some bimodal volcanic-associated massive sulfide systems. In Reviews in Economic Geology. pp. 101-131.

Barrett, T.J., Thompson, J.F.H., and Sherlock, R.L. 1996. Stratigraphic, lithogeochemical and tectonic setting of the Kutcho Creek massive sulphide deposit, northern British Columbia. Exploration and Mining Geology, 5: 309-338.

Bédard, J.H. 1994. A procedure for calculating the equilibrium distribution of trace elements among the minerals of cumulate rocks, and the concentration of trace elements in the coexisting liquids. Chemical Geology, 118: 143-153. doi:10.1016/0009-2541(94)90173-2.

Bickerton, L., Colpron, M., and Gibson, D. 2012. Cache Creek terrane, Stikinia, and overlap assemblages of eastern Whitehorse (NTS 105D) and western Teslin (NTS 105C) map areas. 
614

615

616

617

618

619

620

621

622

623

624

625

626

627

628

629

630

631

632

633

634

635

636

Yukon Geological Research,: 1-17.

Bizimis, M., Salters, V.J.M., and Bonatti, E. 2000. Trace and REE content of clinopyroxenes from supra-subduction zone peridotites. Implications for melting and enrichment processes in island arcs. Chemical Geology, 165: 67-85. doi:10.1016/S0009-2541(99)00164-3.

Bloodgood, M.A., and Bellefontaine, K.A. 1990. The geology of the Atlin area (Dixie Lake and Teresa Island) (104N/6 and parts of 104N/5 and 12). Geological Fieldwork 1989,: 205-215.

Canil, D., Johnston, S.T., and Mihalynuk, M.G. 2006. Mantle redox in Cordilleran ophiolites as a record of oxygen fugacity during partial melting and the lifetime of mantle lithosphere. Earth and Planetary Science Letters, 248: 91-102. doi:10.1016/j.eps1.2006.04.038.

Childe, F., and Schiarizza, P. 1997. U-Pb geochronology, geochemistry and Nd isotopic systematics of the Sitlika assemblage, central British Columbia. Geological Fieldwork 1996,: 69-78.

Childe, F., and Thompson, J. 1997. Geological setting, U-Pb geochronology, and radiogenic isotopic characteristics of the Permo-Triassic Kutcho Assemblage, north-central British Columbia. Canadian Journal of Earth Sciences, 34: 1310-1324. Available from http://www.nrcresearchpress.com/doi/abs/10.1139/e17-104.

Cloos, M. 1993. Lithospheric buoyancy and collisional orogenesis: Subduction of oceanic plateaus, continental margins, island arcs, spreading ridges, and seamounts. Geological Association of America Bulletin, 105: 715-737.

Cordey, F., Gordey, S.P., and Orchard, M.J. 1991. New biostratigraphic data for the northern Cache Creek terrane, Teslin map area, southern Yukon. In Current Research, Part E. Geological Survey of Canada. pp. 67-76. doi:10.1126/science.ns-6.149S.521-a.

Devine, F.A.M. 2002. U-Pb geochronology, geochemistry, and tectonic implications of oceanic 
rocks in the northern Cache Creek Terrane, Nakina area, northwestern British Columbia. University of British Columbia, Vancouver, BC, Canada.

Dilek, Y., and Furnes, H. 2009. Structure and geochemistry of Tethyan ophiolites and their petrogenesis in subduction rollback systems. Lithos, 113: 1-20. Elsevier B.V. doi:10.1016/j.lithos.2009.04.022.

Dilek, Y., Furnes, H., and Shallo, M. 2008. Geochemistry of the Jurassic Mirdita Ophiolite (Albania) and the MORB to SSZ evolution of a marginal basin oceanic crust. Lithos, 100: 174-209. doi:10.1016/j.lithos.2007.06.026.

English, J.M., and Johnston, S.T. 2005. Collisional orogenesis in the northern Canadian Cordillera: Implications for Cordilleran crustal structure, ophiolite emplacement, continental growth, and the terrane hypothesis. Earth and Planetary Science Letters, 232: 333-344. doi:10.1016/j.eps1.2005.01.025.

English, J.M., Mihalynuk, M.G., and Johnston, S.T. 2010. Geochemistry of the northern Cache Creek terrane and implications for accretionary processes in the Canadian Cordillera. Canadian Journal of Earth Sciences, 47: 13-34. doi:10.1139/E09-066.

English, J.M., Mihalynuk, M.G., Johnston, S.T., and Devine, F.A.M. 2002. Atlin TGI Part III : Geology and petrochemistry of mafic rocks within the northern Cache Creek terrane and tectonic implications. Geological Fieldwork 2001,: 19-30.

Gabrielse, H. 1991. Late Paleozoic and Mesozoic terrane interactions in north-central BritishColumbia. Canadian Journal of Earth Sciences, 28: 947-957. doi:10.1139/e91-086.

Gabrielse, H. 1998. Geology of Cry Lake and Dease Lake map areas, north-central British Columbia. In Geological Survey of Canada Bulletin. Geological Survey of Canada Bulletin 504. doi:10.1073/pnas.0703993104. 
660 Gabrielse, H., Monger, J.W.H., Wheeler, J.O., and Yorath, C.J. 1991. Tectonic Framework, Part 661 A: Morphogeological belts, tectonic assemblages and terranes. In Geology of the 662 Cordilleran Orogen in Canada. Edited by H. Gabrielse and C.J. Yorath. Geological Survey 663 of Canada. pp. 15-28.

664 Gale, A., Dalton, C.A., Langmuir, C.H., Su, Y., and Schilling, J.G. 2013. The mean composition 665 of ocean ridge basalts. Geochemistry, Geophysics, Geosystems, 14: 489-518.

666

667

668

669

670 doi:10.1029/2012GC004334.

Gordey, S.P., McNicoll, V.J., and Mortensen, J.K. 1998. New U-Pb ages from the Teslin area, southern Yukon, and their bearing on terrane evolution in the northern Cordillera. In Current Research 1998-F Radiogenic age and isotopic studies: Report 11. Geological Survey of Canada. pp. 129-148.

Ishizuka, O., Tani, K., Reagan, M.K., Kanayama, K., Umino, S., Harigane, Y., Sakamoto, I., Miyajima, Y., Yuasa, M., and Dunkley, D.J. 2011. The timescales of subduction initiation and subsequent evolution of an oceanic island arc. Earth and Planetary Science Letters, 306: 229-240. Elsevier B.V. doi:10.1016/j.eps1.2011.04.006.

675 676 677 678 679 680 681 682

Jenner, G.A. 1996. Trace element geochemistry of igneous rocks: geochemical nomenclature and analytical geochemistry. In Trace element geochemistry of volcanic rocks: Applications for massive sulphide exploration. Edited by D.A. Wyman. Geological Association of Canada, Short Course Notes. pp. 51-77. Available from http://sparky2.esd.mun.ca/ spiercey/Piercey_Research_Site/ES4502_6510_files/Jenner_19 96.pdf.

Johnston, S.T., and Borel, G.D. 2007. The odyssey of the Cache Creek terrane, Canadian Cordillera: Implications for accretionary orogens, tectonic setting of Panthalassa, the Pacific 
superwell, and break-up of Pangea. Earth and Planetary Science Letters, 253: 415-428. doi:10.1016/j.eps1.2006.11.002.

Kelemen, P.B., and Dick, H.J.B. 1995. Focused melt flow and localized deformation in the upper mantle: Juxtaposition of replacive dunite and ductile shear zones in the Josephine peridotite, SW Oregon. Journal of Geophysical Research, 100: 423-438. doi:10.1029/94JB02063.

Kimura, G., and Ludden, J. 1995. Peeling oceanic crust in subduction zones. Geology, 23: 217220. doi:10.1130/0091-7613(1995)023<0217.

Kinzler, R.J., and Grove, T.L. 1992. Primary magmas of mid-ocean ridge basalts 2. Applications. Journal of Geophysical Research, 97: 6907-6926. doi:10.1029/91JB02841.

Lagabrielle, Y., Vitale Brovarone, A., and Ildefonse, B. 2015. Fossil oceanic core complexes recognized in the blueschist metaophiolites of Western Alps and Corsica. Earth-Science Reviews, 141: 1-26. Elsevier B.V. doi:10.1016/j.earscirev.2014.11.004.

Langmuir, C.H. 1989. Geochemical consequences of in situ crystallization. doi:10.1038/340199a0.

Lapierre, H., Bosch, D., Tardy, M., and Struik, L.C. 2003. Late Paleozoic and Triassic plumederived magmas in the Canadian Cordillera played a key role in continental crust growth. Chemical Geology, 201: 55-89. doi:10.1016/S0009-2541(03)00224-9.

MacLean, W.H. 1990. Mass change calculations in altered rock series. Mineralium Deposita, 25: 44-49. doi:10.1007/BF03326382.

Maffione, M., Morris, A., and Anderson, M.W. 2013. Recognizing detachment-mode seafloor spreading in the deep geological past. Scientific reports, 3: 2336. doi:10.1038/srep02336.

Maffione, M., Thieulot, C., Van Hinsbergen, D.J.J., Morris, A., Plumper, O., and Spakman, W. 2015. Dynamics of intraoceanic subduction initiation: 1. Oceanic detachment fault inversion 
and the formation of supra-subduction zone ophiolites. Geochemistry Geophysics Geosystems, 16: 1753-1770. doi:10.1002/2015GC005745.Dynamics.

Le Maitre, R.W. 1989. A classification of igneous rocks and glossary of terms. Blackwell Books, Oxford, UK.

McGoldrick, S., Zagorevski, A., Canil, D., Corriveau, A.-S., Bichlmaier, S., and Carroll, S. 2016. Geology of the Cache Creek terrane in the Peridotite Peak - Menatatuline Range Area, northwestern British Columbia (Parts of NTS 104K/15 , /16). Geoscience BC Summary of Activities 2015,: 149-162.

Merran, Y. 2002. Mise en place et environnement de depot d'une plate-forme carbonatée intraoceanique: example du complexe d'Atlin, Canada. Université Claude Bernard, France.

Mihalynuk, M.G. 1999. Geology and mineral resources of the Tagish Lake area (NTS 104M/8,9,10E,15 and 104N/12W) northwestern British Columbia. In Bulletin 105. British Columbia Geological Survey.

Mihalynuk, M.G., Bellefontaine, K.A., Brown, D.A., Logan, J.M., Nelson, J.L., Legun, A.S., and Diakow, L.J. 1996. Geological compilation, northwest British Columbia (NTS 94E, L, M; 104F, G, H, I, J, K, L, M, N, O, P; 114J, O, P). BC Ministry of Energy and Mines.

Mihalynuk, M.G., and Cordey, F. 1997. Potential for Kutcho Creek volcanogenic massive sulphide mineralization in the northern Cache Creek terrane: a progress report. Geological Fieldwork 1996,: 157-170.

Mihalynuk, M.G., Erdmer, P., Ghent, E.D., Archibald, D.A., Friedman, R.M., Cordey, F., Johannson, G.G., and Beanish, J. 1998. Age constraints for emplacement of the northern cache creek terrane and implications of blueschist metamorphism. Geological Fieldwork 1997,: 127-141. 
Mihalynuk, M.G., Erdmer, P., Ghent, E.D., Cordey, F., Archibald, D.A., Friedman, R.M., and Johannson, G.G. 2004a. Coherent French Range blueschist: Subduction to exhumation in less than 2.5 m.y.? Geological Society of America Bulletin, 116: 910-922. doi:10.1130/B25393.1.

Mihalynuk, M.G., Fiererra, L., Robertson, S., Devine, F.A.M., and Cordey, F. 2004b. Geology and new mineralization in the Joss'alun belt, Atlin area. Geological Fieldwork 2003,: 6182.

Mihalynuk, M.G., Johnston, S.T., English, J.M., Cordey, F., Villeneuve, M.E., Rui, L., and Orchard, M.J. 2003. Atlin TGI , Part II : Regional geology and mineralization of the Nakina area (NTS 104N / 2W and 3). Geological Fieldwork 2002,: 9-38.

Mihalynuk, M.G., Johnston, S.T., Lowe, C., Cordey, F., English, J.M., Devine, F.A.M., Larson, K., and Merran, Y. 2002. Atlin TGI Part II : Preliminary results from the Atlin Targeted Geoscience Initiative, Nakina area, northwest British Columbia. Geological Fieldwork 2001,: 5-18.

Mihalynuk, M.G., Nelson, J.A., and Diakow, L.J. 1994. Cache Creek terrane entrapment: oroclinal paradox within the Canadian Cordillera. Tectonics, 13: 575-595. doi:10.1029/93TC03492.

Mihalynuk, M.G., Smith, M.T., Gabites, J.E., Runkle, D., and Lefebure, D. 1992. Age of emplacement and basement character of the Cache Creek terrane as constrained by new isotopic and geochemical data. Canadian Journal of Earth Sciences, 29: 2463-2477. doi:10.1139/e92-193.

Monger, J.W.H. 1975. Upper Paleozoic rocks of the Atlin terrane, northwestern British Columbia and south-central Yukon. Geological Survey of Canada Paper 74-47. 
752

753

754

755

756

757

758

759

760

761

762

763

764

765

766

767

768

769

770

771

772

773

774

Monger, J.W.H. 1977. Upper Paleozoic rocks of northwestern British Columbia. In Report of Activities, Part A. Geological Survey of Canada. pp. 255-262. doi:10.1038/074245b0.

Monger, J.W.H., and Ross, C.A. 1971. Distribution of Fusulinaceans in the western Canadian Cordillera. Canadian Journal of Earth Sciences, 8: 259-278. doi:10.1139/e71-026.

Natural Resources Canada. 1990a. Teditua Creek NTS 104K/16, 1:50 000 scale raster image. Natural Resources Canada.

Natural Resources Canada. 1990b. Yeth Creek NTS 104K/15, 1:50 000 scale raster image. Natural Resources Canada.

Nelson, J.A., and Colpron, M. 2007. Tectonics and metallogeny of the British Columbia, Yukon and Alaskan Cordillera, 1.8 Ga to the present. In Mineral Deposits of Canada: A synthesis of major deposit types, district metallogeny, the evolution of geological provinces, and exploration methods. Edited by W.D. Goodfellow. Geological Association of Canada, Mineral Deposits Division. pp. 755-791.

Nelson, J.A., and Colpron, M. 2011. A digital atlas of terranes for the northern Cordillera.

Niu, Y.L., and Batiza, R. 1991. An empirical method for calculating melt compositions produced beneath ridges: Application for axis and off-axis (seamounts) melting. Journal of Geophysical Research, 96: 21753-21777.

Ohara, Y., Fujioka, K., Ishii, T., and Yurimoto, H. 2003. Peridotites and gabbros from the Parece Vela backarc basin: Unique tectonic window in an extinct backarc spreading ridge. Geochemistry, Geophysics, Geosystems, 4: n/a-n/a. doi:10.1029/2002GC000469.

Orchard, M.J., Cordey, F., Rui, L., Bamber, E.W., Mamet, B., Struik, L.C., Sano, H., and Taylor, H.J. 2001. Biostratigraphic and biogeographic constraints on the Carboniferous to Jurassic Cache Creek Terrane in central British Columbia. Canadian Journal of Earth Sciences, 38: 
551-578. doi:10.1139/e00-120.

Pearce, J.A. 1982. Trace element characteristics of lavas from destructive plate boundaries. In Orogenic andesites and related rocks. Edited by R.S. Thorpe. John Wiley and Sons, Chichester, UK. pp. 525-548.

Pearce, J.A. 1996. A user's guide to basalt discrimination diagrams. In Trace element geochemistry of volcanic rocks: Applications for massive sulphide exploration. Edited by D.A. Wyman. Geological Association of Canada, Short Course Notes. pp. 79-113.

Pearce, J.A., and Norry, M.J. 1979. Petrogenetic implications of Ti, Zr, Y, and Nb variations in volcanic rocks. Contributions to Mineralogy and Petrology, 69: 33-47. doi:10.1007/BF00375192.

Pearce, J.A., and Peate, D.W. 1995. Tectonic implications of the composition of volcanic arc magmas. Annual Review of Earth and Planetary Sciences, 23: 251-285.

Pomonis, P., Tsikouras, B., and Hatzipanagiotou, K. 2006. Petrogenetic evolution of the Koziakas ophiolite complex (W. Thessaly, Greece). Mineralogy and Petrology, 89: 77-111. doi:10.1007/s00710-006-0138-4.

Reagan, M.K., Ishizuka, O., Stern, R.J., Kelley, K.A., Ohara, Y., Blichert-Toft, J., Bloomer, S.H., Cash, J., Fryer, P., Hanan, B.B., Hickey-Vargas, R., Ishii, T., Kimura, J.I., Peate, D.W., Rowe, M.C., and Woods, M. 2010. Fore-arc basalts and subduction initiation in the Izu-Bonin-Mariana system. Geochemistry, Geophysics, Geosystems, 11: 1-17. doi:10.1029/2009GC002871.

Reagan, M.K., McClelland, W.C., Girard, G., Goff, K.R., Peate, D.W., Ohara, Y., and Stern, R.J. 2013. The geology of the southern Mariana fore-arc crust: Implications for the scale of Eocene volcanism in the western Pacific. Earth and Planetary Science Letters, 380: 41-51. 


$$
\text { Elsevier B.V. doi:10.1016/j.eps1.2013.08.013. }
$$

Ross, P.-S., and Bédard, J.H. 2009. Magmatic affinity of modern and ancient subalkaline volcanic rocks determined from trace-element discriminant diagrams. Canadian Journal of Earth Sciences, 46: 823-839. doi:10.1139/E09-054.

Saccani, E., and Photiades, A. 2004. Mid-ocean ridge and supra-subduction affinities in the Pindos ophiolites (Greece): Implications for magma genesis in a forearc setting. Lithos, 73: 229-253. doi:10.1016/j.lithos.2003.12.002.

Saunders, A.D., Norry, M., and Tarney, J. 1988. Origin of MORB and chemically-depleted mantle reservoirs: Trace element constraints. Journal of Petrology,: 415-445.

Schiarizza, P. 2012. Geology of the Kutcho assemblage between the Kehlechoa and Tucho Rivers, northern British Columbia (NTS 104I / 01 , 02). Geological Fieldwork 2011,: 7598.

Smith, I.E.M., and Price, R.C. 2006. The Tonga-Kermadec arc and Havre-Lau back-arc system: Their role in the development of tectonic and magmatic models for the western Pacific. Journal of Volcanology and Geothermal Research, 156: 315-331. doi:10.1016/j.jvolgeores.2006.03.006.

Souther, J.G. 1971. Geology and mineral deposits of Tulsequah map area, British Columbia (104K). Geological Survey of Canada Memoir, 362: 1-84. doi:10.1017/CBO9781107415324.004.

Stern, R.J., Reagan, M.K., Ishizuka, O., Ohara, Y., and Whattam, S.A. 2012. To understand subduction initiation, study forearc crust: To understand forearc crust, study ophiolites. Lithosphere,: 469-483. doi:10.1130/L183.1.

Struik, L.C., Schiarizza, P., Orchard, M.J., Cordey, F., Sano, H., MacIntyre, D.G., Lapierre, H., 
and Tardy, M. 2001. Imbricate architecture of the upper Paleozoic to Jurassic oceanic Cache Creek Terrane, central British Columbia. Canadian Journal of Earth Sciences, 38: 495-514. doi:10.1139/cjes-38-4-495.

Sun, C., and Liang, Y. 2014. An assessment of subsolidus re-equilibration on REE distribution among mantle minerals olivine, orthopyroxene, clinopyroxene, and garnet in peridotites. Chemical Geology, 372: 80-91. Elsevier B.V. doi:10.1016/j.chemgeo.2014.02.014.

Sun, S., and McDonough, W.F. 1989. Chemical and isotopic systematics of oceanic basalts: implications for mantle composition and processes. In Magmatism in the ocean basins. Edited by A.D. Saunders and M.J. Norry. Geological Society of London. pp. 313-345. Tamura, Y., Tatsumi, Y., Zhao, D., Kido, Y., and Shukuno, H. 2002. Hot fingers in the mantle wedge: New insights into magma genesis in subduction zones. Earth and Planetary Science Letters, 197: 105-116. doi:10.1016/S0012-821X(02)00465-X.

Tardy, M., Lapierre, H., Struik, L.C., Bosch, D., and Brunet, P. 2001. The influence of mantle plume in the genesis of the Cache Creek oceanic igneous rocks: implications for the geodynamic evolution of the inner accreted terranes of the Canadian Cordillera. Canadian Journal of Earth Sciences, 38: 515-534.

Tempelman-Kluit, D.J. 1979. Transported cataclasite, ophiolite and granodiorite in Yukon: Evidence of arc-continent collision. Geological Survey of Canada Paper 79-14.

Terry, J. 1977. Geology of the Nahlin ultramafic body, Atlin and Tulsequah map-areas, northwestern British Columbia. In Report of Activities, Part A. Geological Survey of Canada. pp. 263-269.

Todd, E., Gill, J.B., Wysoczanski, R.J., Hergt, J., Wright, I.C., Leybourne, M.I., and Mortimer, N. 2011. Hf isotopic evidence for small-scale heterogeneity in the mode of mantle wedge 
844

845

846

847

848

849

850

851

852

853

854

855

856

857

858

859

860

861

862

863

864

865

866

enrichment: Southern Havre Trough and South Fiji Basin back arcs. Geochemistry, Geophysics, Geosystems, 12. doi:10.1029/2011GC003683.

Uysal, I., Ersoy, E.Y., Dilek, Y., Kapsiotis, A., and Sarıfakığlu, E. 2016. Multiple episodes of partial melting, depletion, metasomatism and enrichment processes recorded in the heterogeneous upper mantle sequence of the Neotethyan Eldivan ophiolite, Turkey. Lithos, 246-247: 228-245. doi:10.1016/j.lithos.2016.01.004.

Warren, J.M. 2016. Global variations in abyssal peridotite compositions. Lithos, 248-251: $193-$ 219. The Author. doi:10.1016/j.lithos.2015.12.023.

Warren, J.M., and Shimizu, N. 2010. Cryptic variations in abyssal peridotite compositions: Evidence for shallow-level melt infiltration in the oceanic lithosphere. Journal of Petrology, 51: 395-423. doi:10.1093/petrology/egp096.

Wasylenki, L.E., Baker, M.B., Kent, A.J.R., and Stolper, E.M. 2003. Near-solidus melting of the shallow upper mantle: Partial melting experiments on depleted peridotite. Journal of Petrology, 44: 1163-1191. doi:10.1093/petrology/44.7.1163.

Whattam, S.A., and Stern, R.J. 2011. The "subduction initiation rule": A key for linking ophiolites, intra-oceanic forearcs, and subduction initiation. Contributions to Mineralogy and Petrology, 162: 1031-1045. doi:10.1007/s00410-011-0638-z.

Wilson, S.C., Murton, B.J., and Taylor, R.N. 2013. Mantle composition controls the development of an Oceanic Core Complex. Geochemistry, Geophysics, Geosystems, 14: 979-995. doi:10.1002/ggge.20046.

Workman, R.K., and Hart, S.R. 2005. Major and trace element composition of the depleted MORB mantle (DMM). Earth and Planetary Science Letters, 231: 53-72. doi:10.1016/j.eps1.2004.12.005. 
867

868

869

870

Wysoczanski, R.J., Todd, E., Wright, I.C., Leybourne, M.I., Hergt, J.M., Adam, C., and Mackay, K. 2010. Backarc rifting, constructional volcanism and nascent disorganised spreading in the southern Havre Trough backarc rifts (SW Pacific). Journal of Volcanology and Geothermal Research, 190: 39-57. Elsevier B.V. doi:10.1016/j.jvolgeores.2009.04.004.

Zagorevski, A. 2016. Geochemical data of the northern Cache Creek and Stikine terranes and their overlap assemblages, British Columbia and Yukon. Geological Survey of Canada Open File, 8039: 1-11. doi:10.4095/299347.

Zagorevski, A., Corriveau, A.-S., McGoldrick, S., Bédard, J.H., Canil, D., Golding, M.L., Joyce, N., and Mihalynuk, M.G. 2015. Geological framework of ancient oceanic crust in northwestern British Columbia and southwestern Yukon GEM 2 Cordillera. Geological Survey of Canada Open File, 7957: 1-10. doi:10.4095/297273.

Zagorevski, A., Lissenberg, C.J., and van Staal, C.R. 2009. Dynamics of accretion of arc and backarc crust to continental margins: Inferences from the Annieopsquotch accretionary tract, Newfoundland Appalachians. Tectonophysics, 479: 150-164. Elsevier B.V. doi:10.1016/j.tecto.2008.12.002.

Zagorevski, A., Mihalynuk, M.G., Joyce, N., and Anderson, R.G. 2017. Late Cretaceous magmatism in the Atlin-Tagish area, northern British Columbia (104M , 104N). Geological Fieldwork 2016,: 133-152.

Zagorevski, A., Mihalynuk, M.G., McGoldrick, S., Bédard, J.H., Golding, M.L., Joyce, N., Lawley, C., Canil, D., Corriveau, A.-S., Bogatu, A., and Tremblay, A. 2016a. Geological framework of ancient oceanic crust in northwestern British Columbia and southwestern Yukon GEM 2 Cordillera. Geological Survey of Canada Open File, 8140: 1-13. doi:10.4095/297273. 
890 Zagorevski, A., Mihalynuk, M.G., Milidragovic, D., Joyce, N., Kovacs, N., Allan, M., Friedman, 891 R.M., and Kellett, D.A. 2016b. Characterization of volcanic and intrusive rocks across the 892 British Columbia - Yukon border, GEM 2 Cordillera. Geological Survey of Canada Open $893 \quad$ File, 8141: 1-13. doi:10.4095/297272.

894 Zagorevski, A., and van Staal, C.R. 2011. The Record of Ordovician arc-arc and arc-continent 895 collisions in the Canadian Appalachians during the closure of Iapetus. In Frontiers in Earth 896 Sciences. Edited by D. Brown and P.D. Ryan. Springer-Verlag Berlin Heidelberg. pp. 341897 371. doi:10.1007/978-3-540-88558-0.

898 
Table 1: Summary of ophiolitic and arc rocks in the northern Cache Creek terrane

\begin{tabular}{llll}
\hline Map & \multicolumn{1}{c}{ Location } & \multicolumn{1}{c}{ Lithologies } & Affinity \\
\hline A & King Mountain (BC) & ophiolite, mantle, gabbro, dykes & IAT, BON \\
B & Kutcho & bimodal volcanic rocks & IAT \\
C & Nakina area (BC) & quartz diorite intruding into mantle & IAT \\
D & Tseta Creek (BC) & diorite in mafic volcanic and intrusive rocks & IAT \\
E & Graham Creek (BC) & basalt, diabase, mantle and chert & BAB \\
F & Jakes Corner (YK) & gabbro stitching mantle and basalt & IAT \\
G & Teslin (YK) & trondhjemite in ophiolite & IAT \\
\hline
\end{tabular}

${ }^{* 1}$ Zagorevski et al. (2016a), 'Zagorevski et al.(2016c), ${ }^{3}$ Schiarrizza (2011), ${ }^{4}$ Childe and Thomr

${ }^{7}$ Mihalynuk et al. (2003), ${ }^{8}$ Mihalynuk et al. (1998); ${ }^{9}$ Zagorevski et al. (2017) ${ }^{10}$ Gordey et al. (: 


\begin{tabular}{lll}
\hline \multicolumn{1}{c}{ Method } & \multicolumn{1}{c}{ Age (Ma) } & Reference $^{*}$ \\
\hline U-Pb zrn, ttn; Ar-Ar hbl & ca. 250-255 & 1,2 \\
U-Pb zrn & ca. 242-251.71 & 3,4 \\
U-Pb zrn & $255 \pm 2.8$ & $5,6,2$ \\
U-Pb zrn & $261.4 \pm 0.3$ & 6,7 \\
Radiolaria & Middle Triassic & 8,9 \\
U-Pb zrn & ca. 245 & 1,2 \\
U-Pb zrn & $245.4 \pm 0.8$ & $1,2,8$ \\
\hline
\end{tabular}

Json (1997), 'Devine (2002), 'English et al. (2010),

1998) 
Figure 1

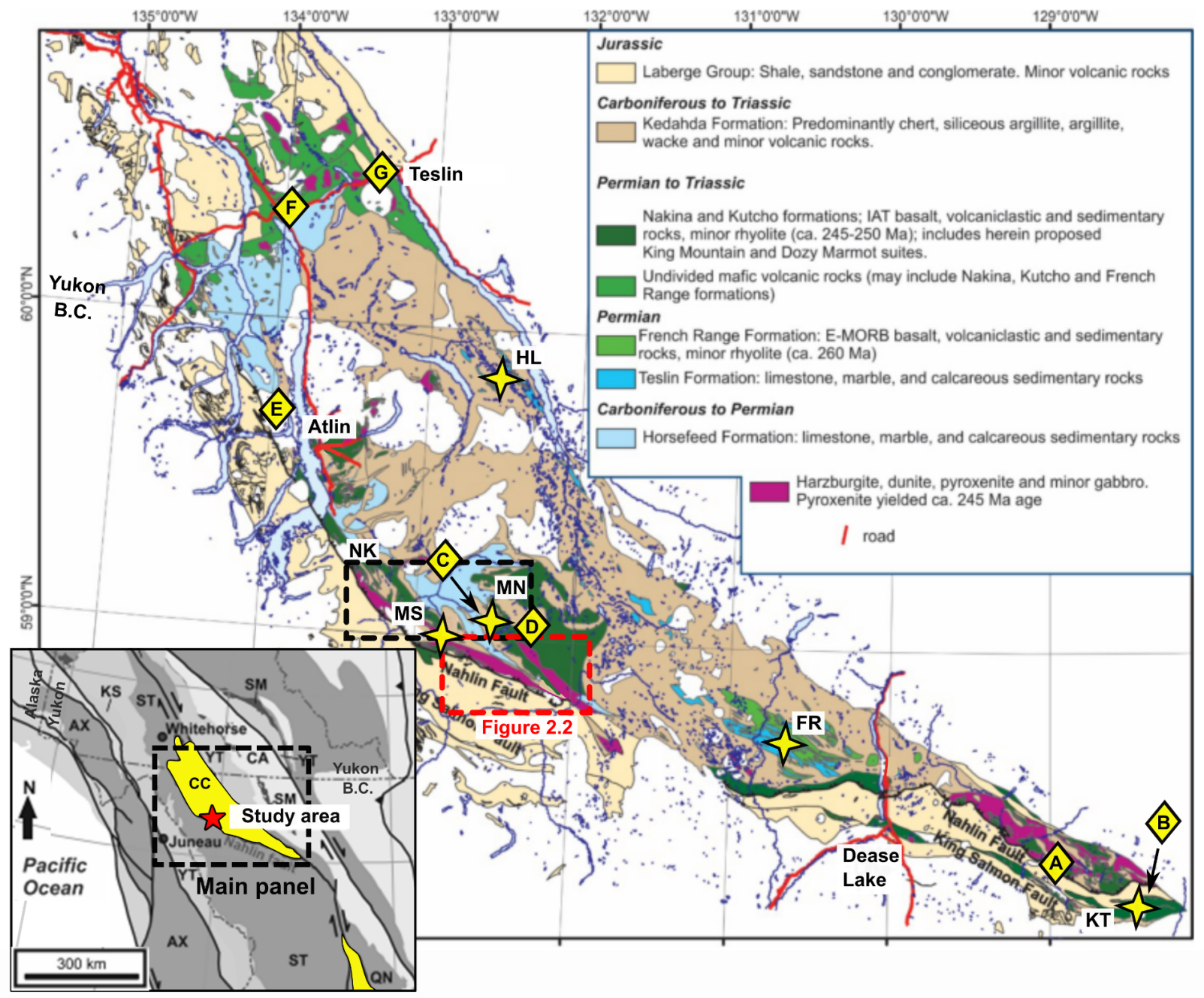




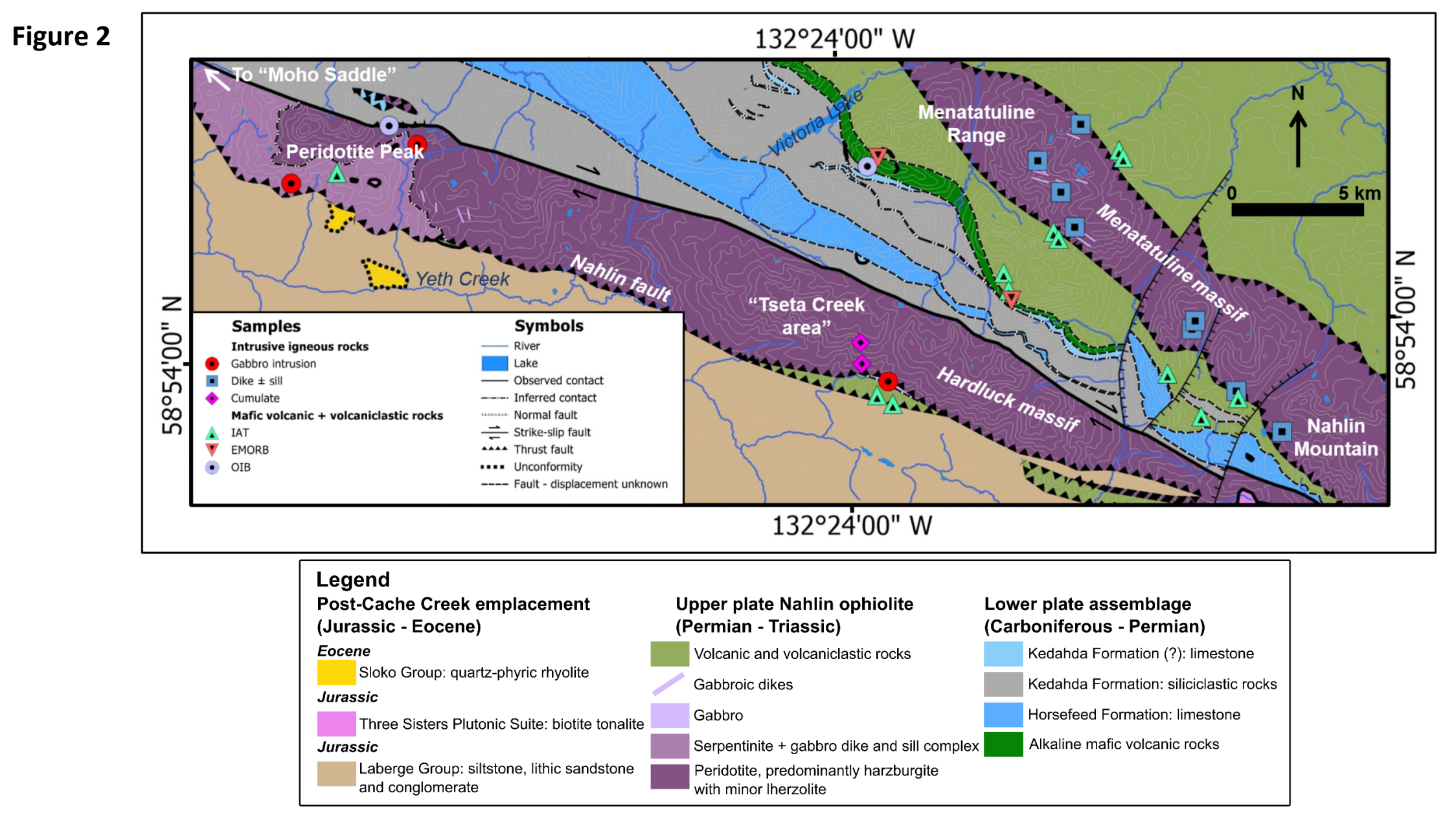


Figure 3
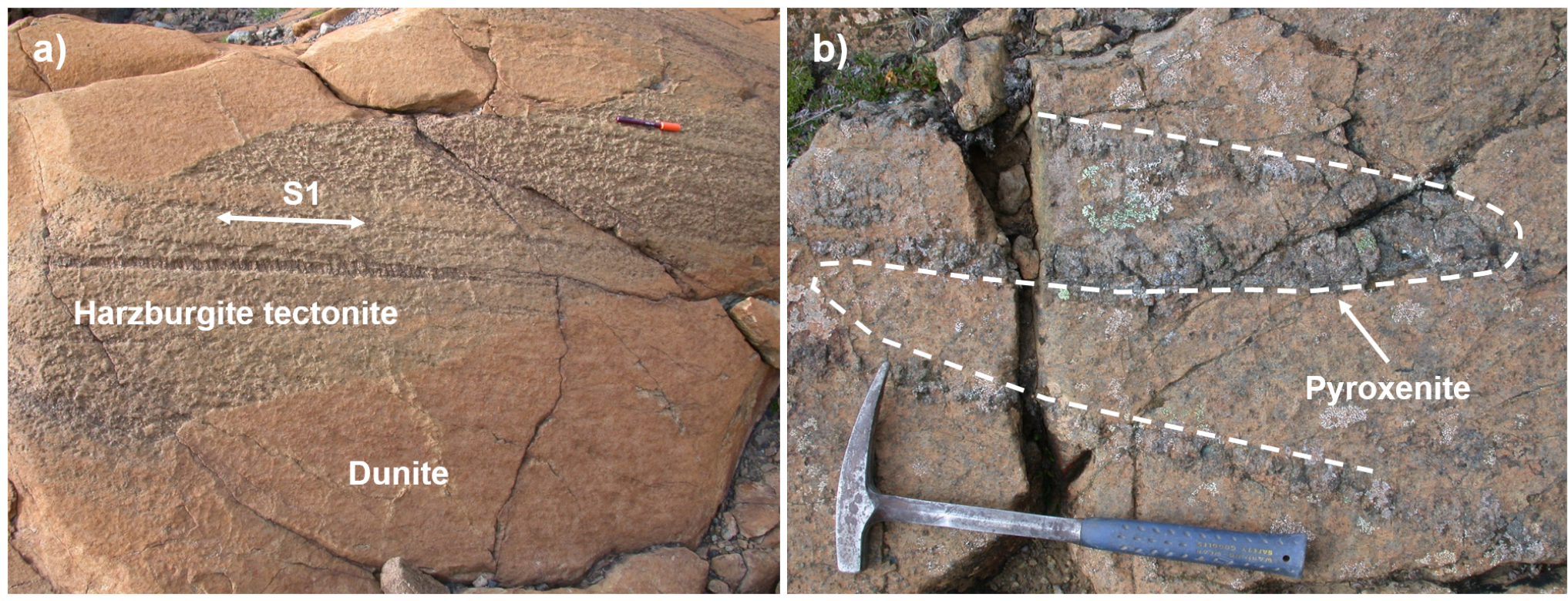
Figure 4
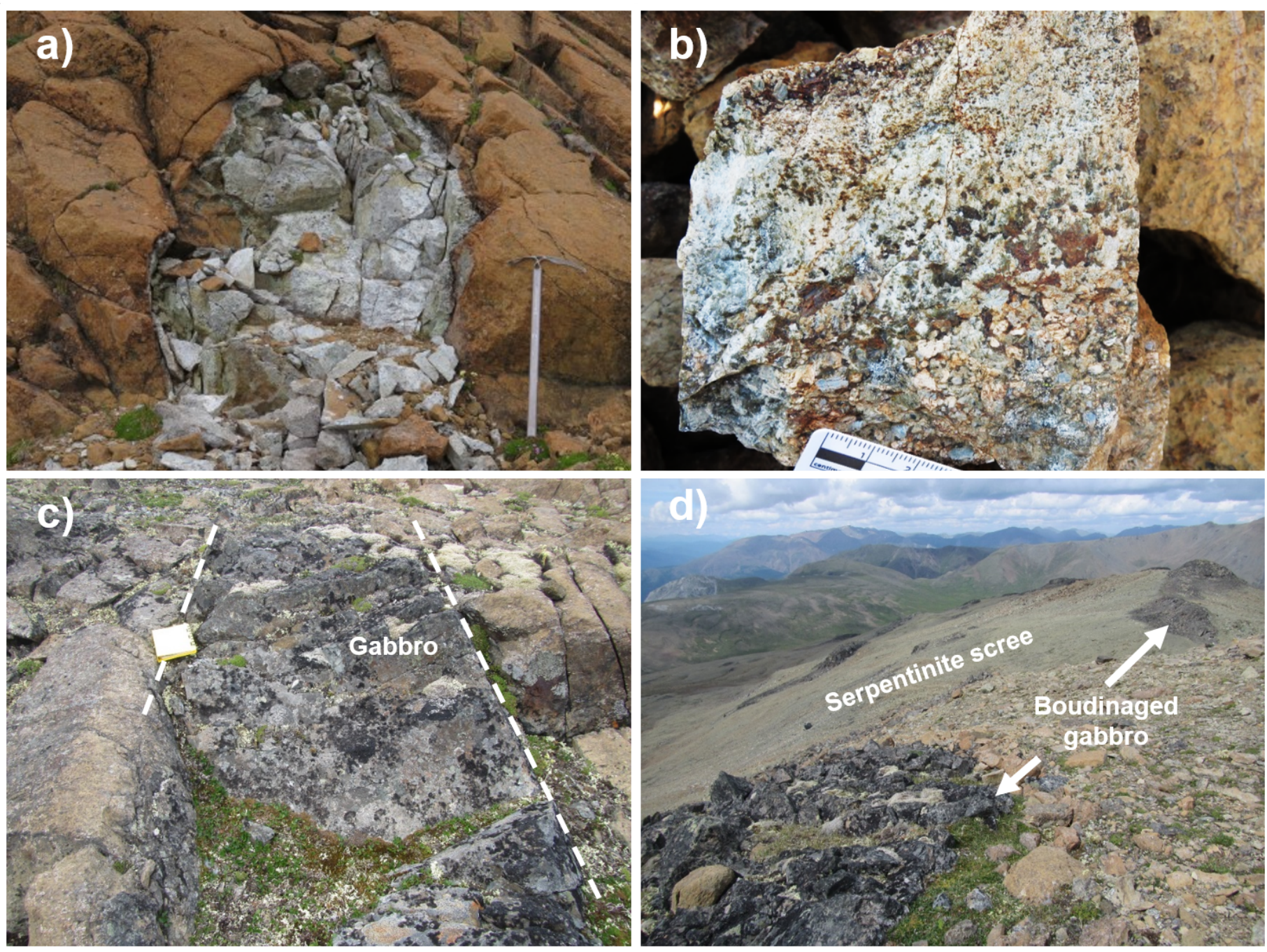
Figure 5

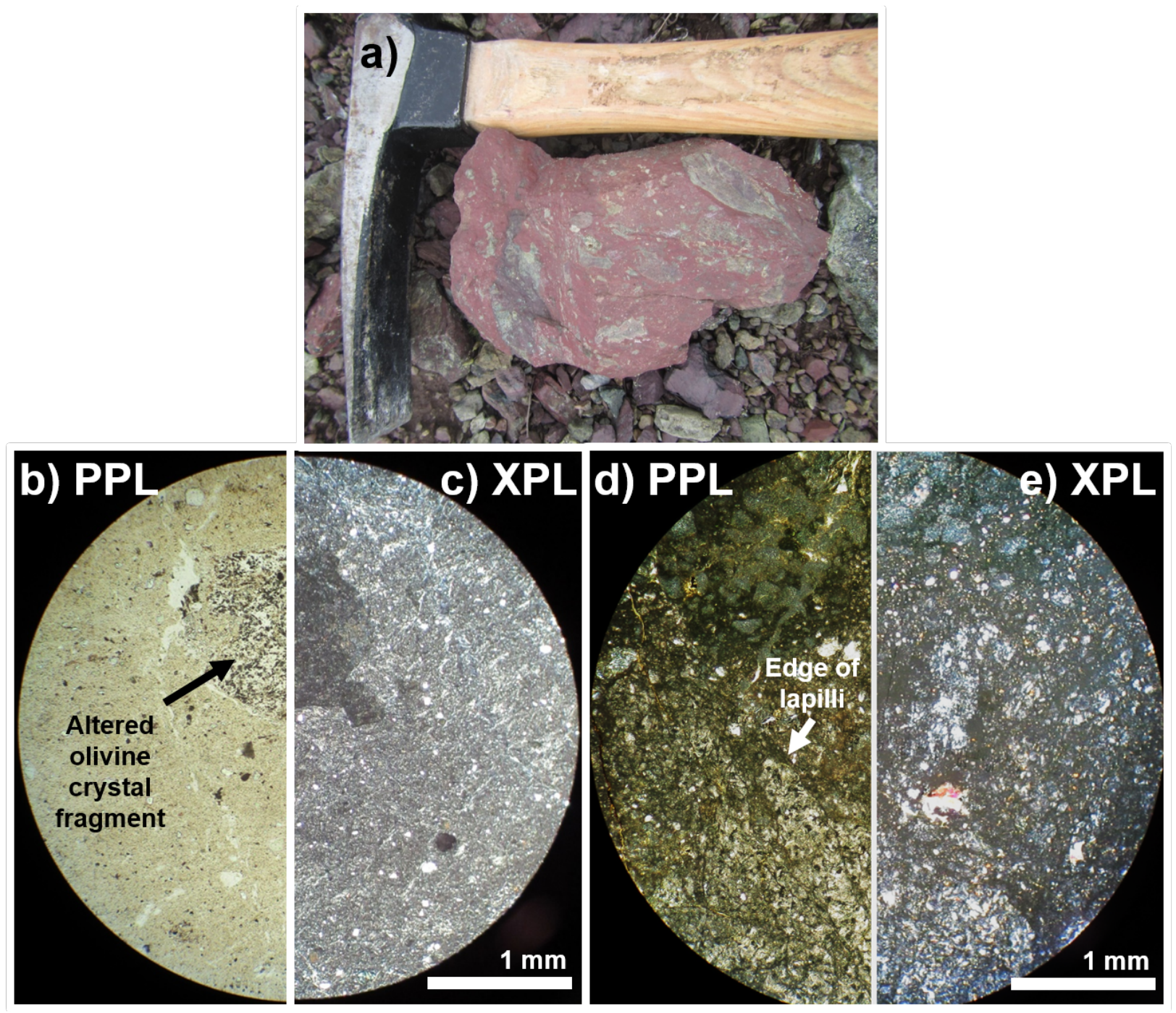


Figure 6
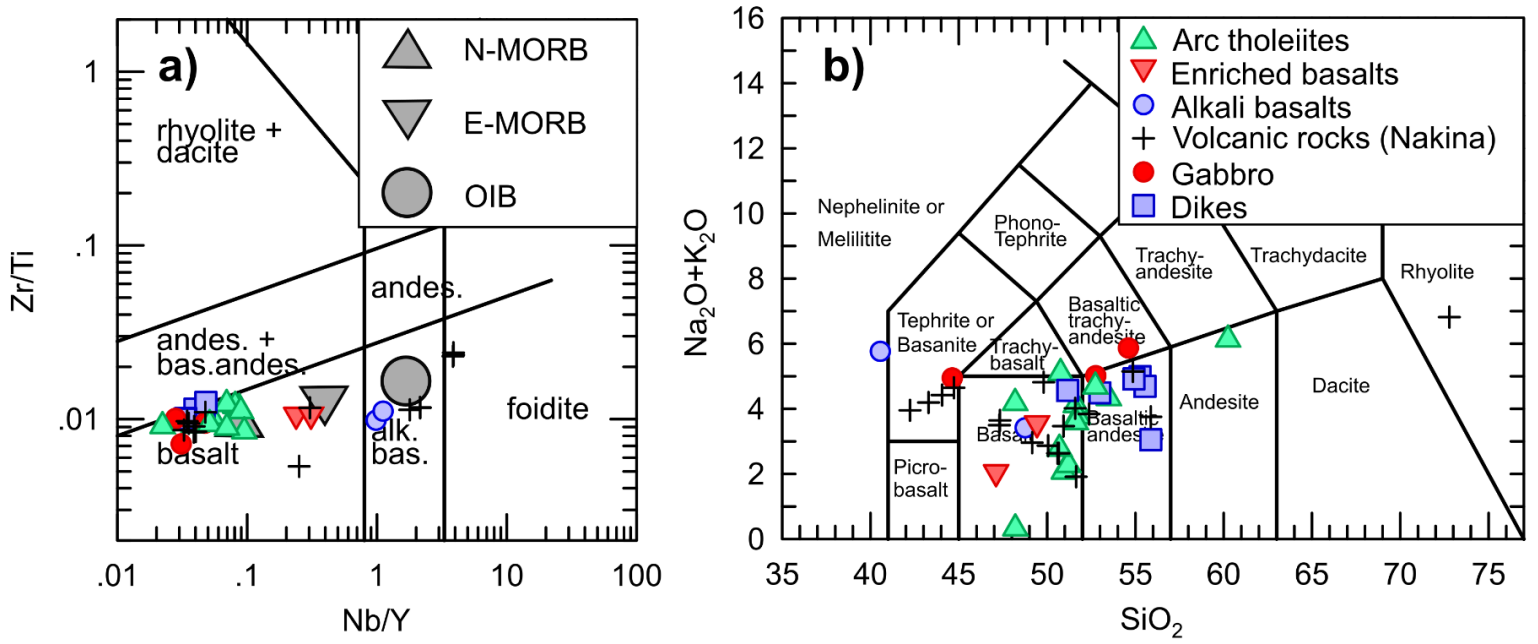
Figure 7

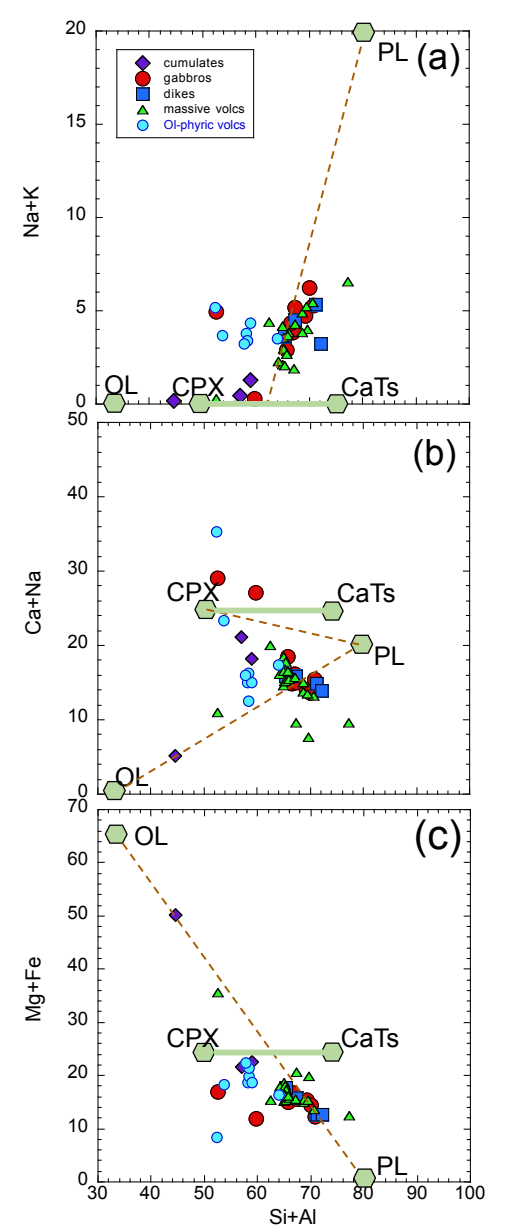

https://mc06.manuscriptcentral.com/cjes-pubs 
Figure 8
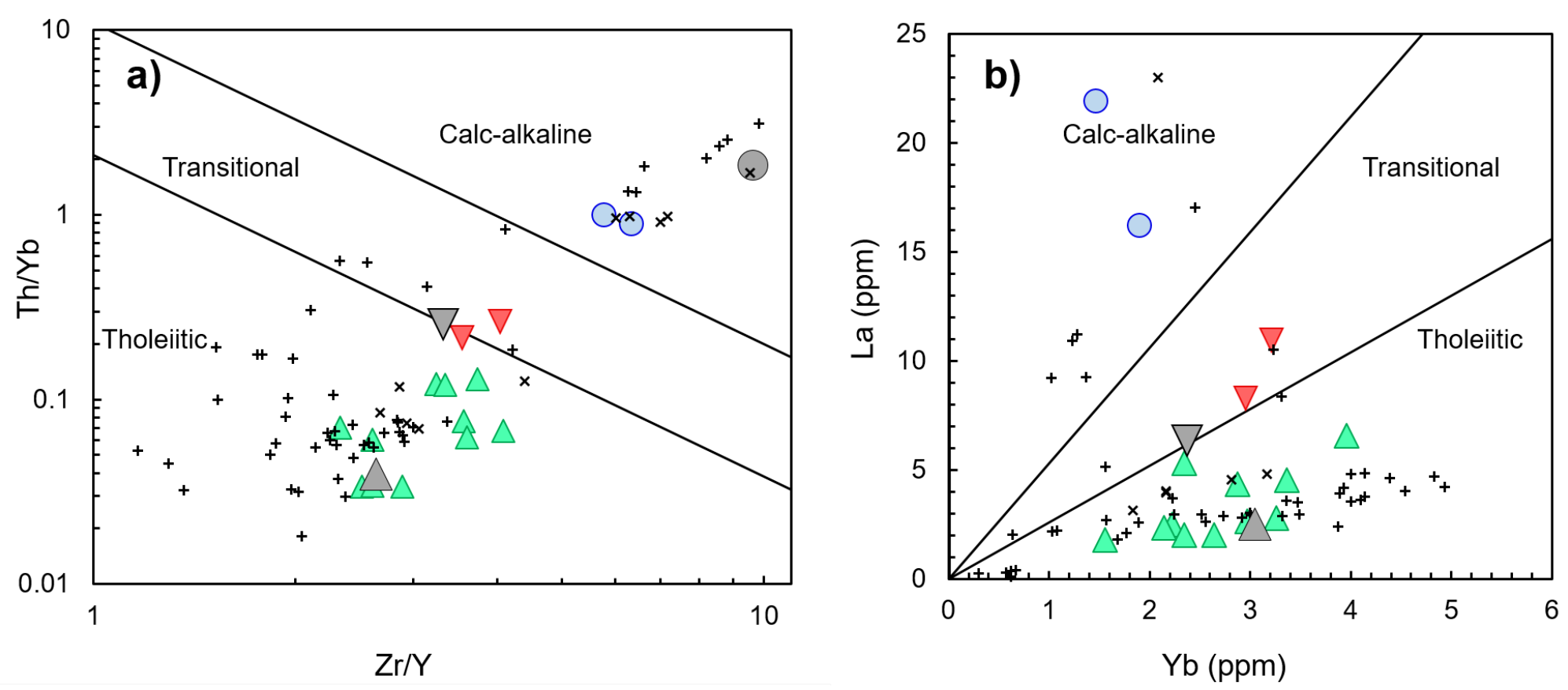
Figure 9

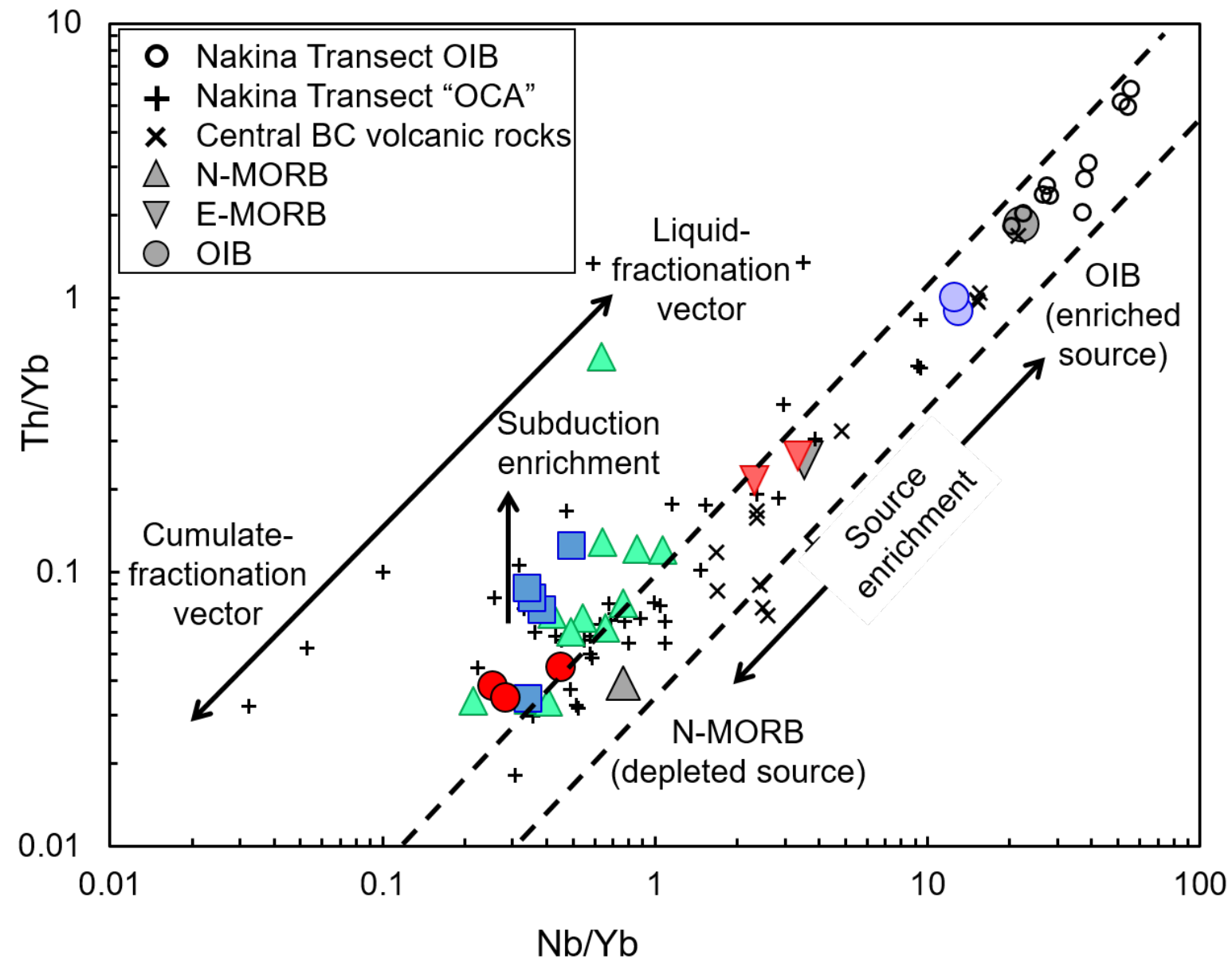


Figure 10
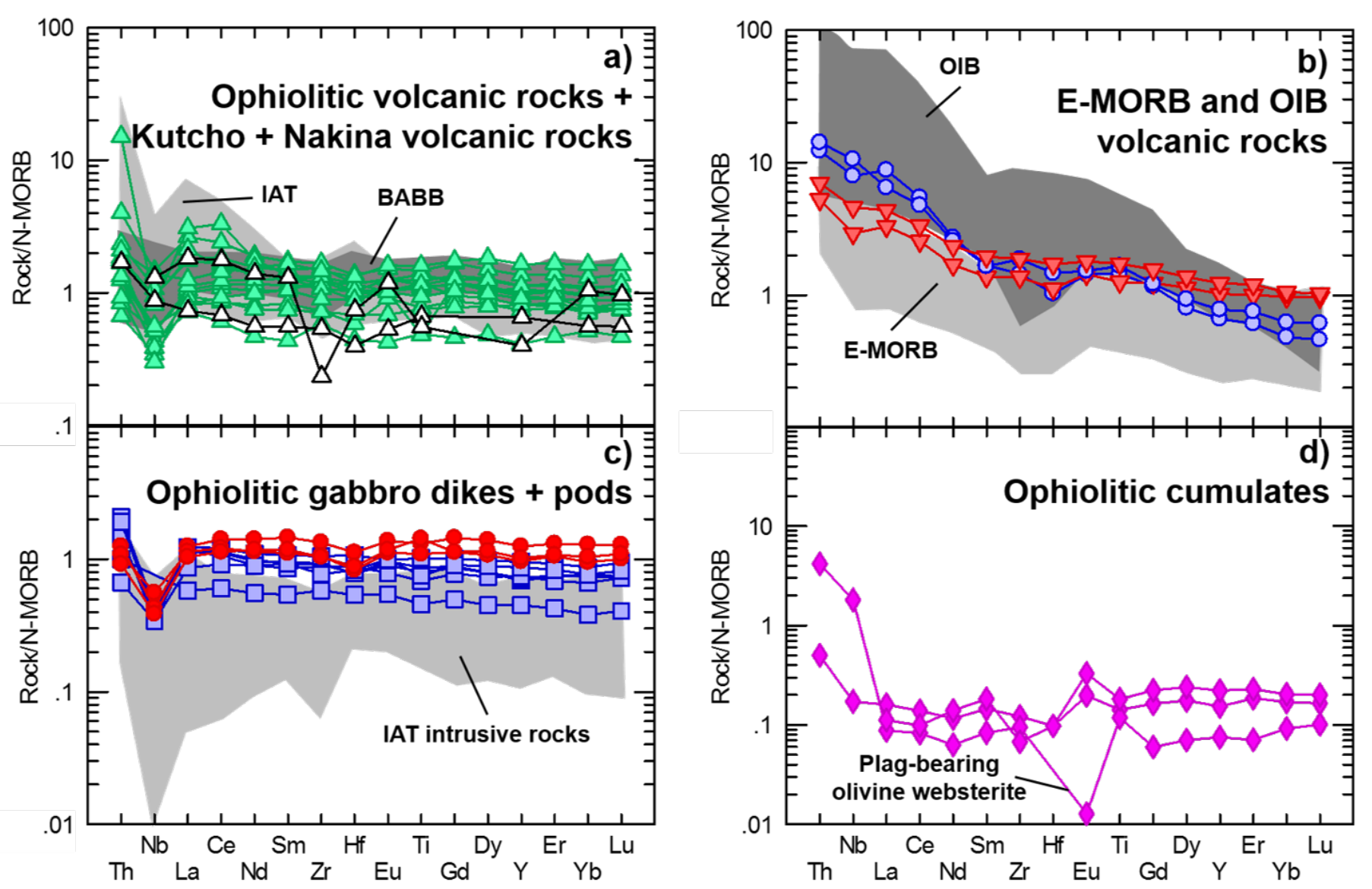
Figure 11

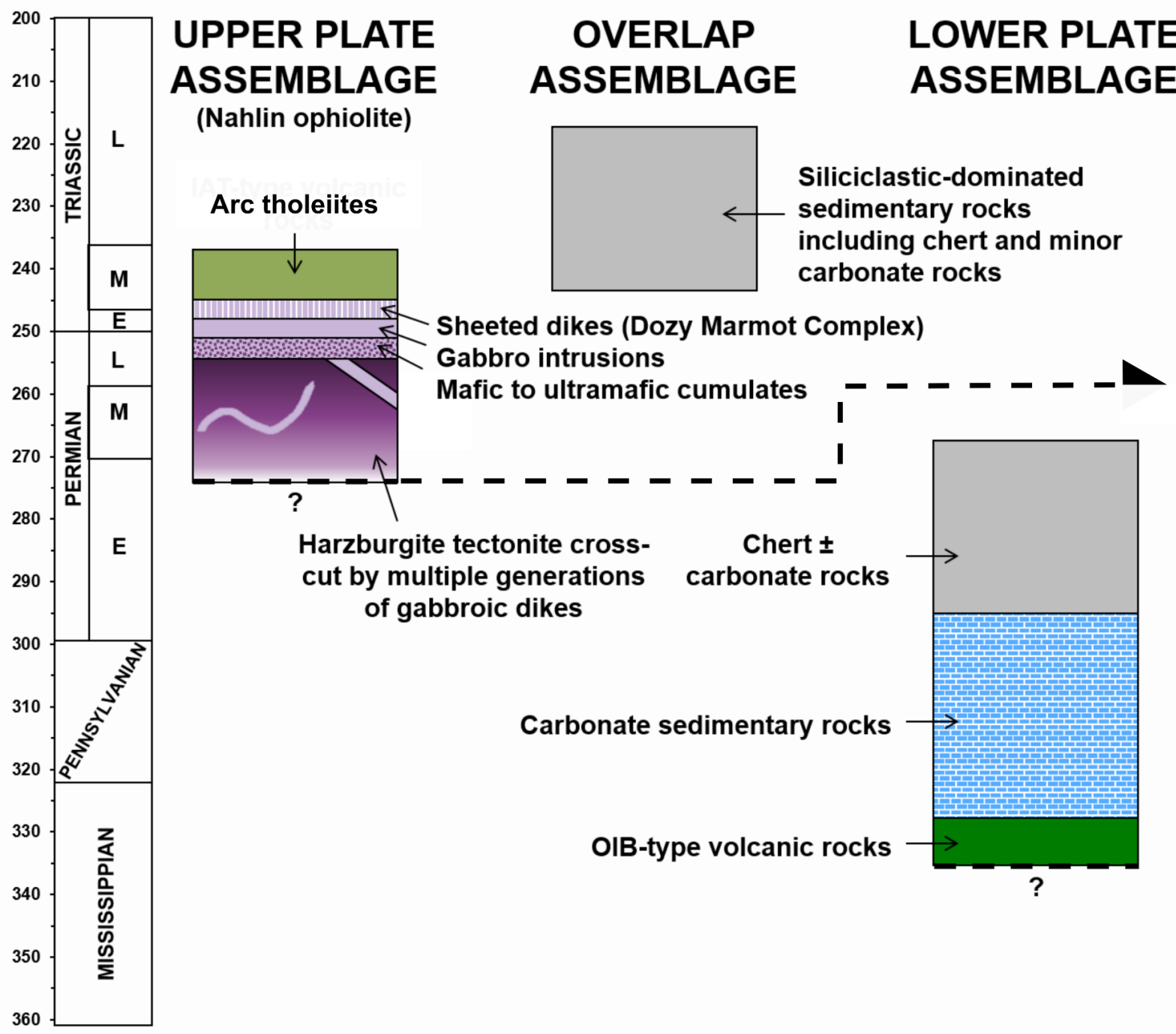


Figure 12
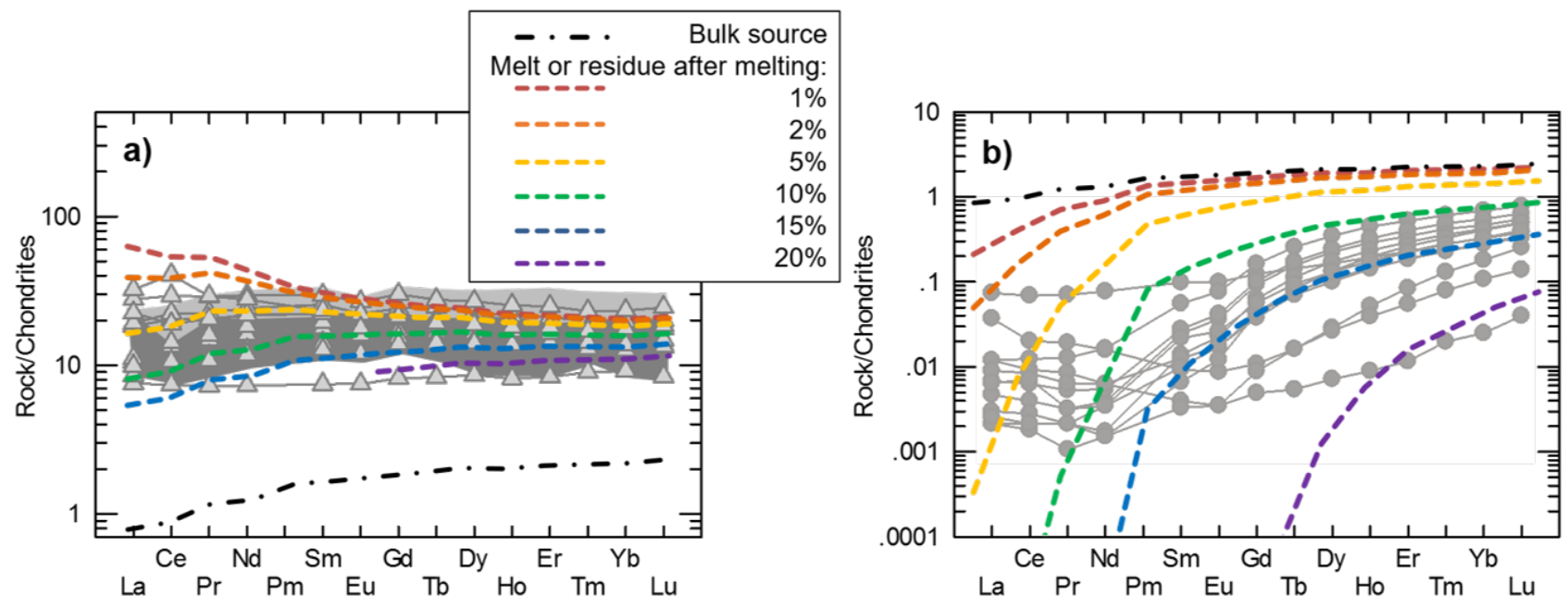
Figure 13

a)

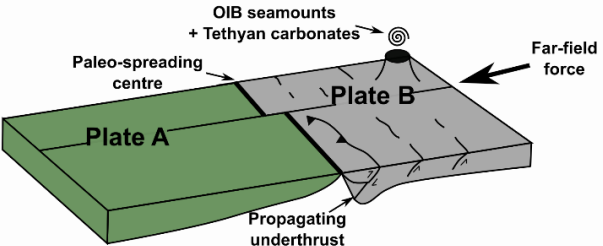

b)

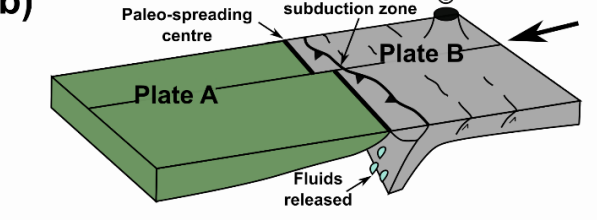

c)

$$
\text { Forearc }
$$

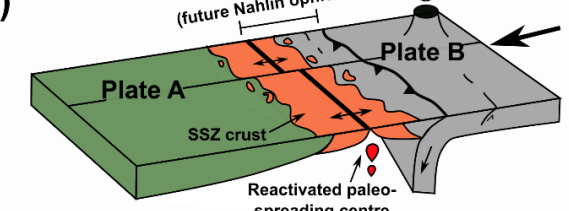

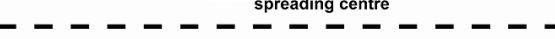

d) $\begin{gathered}\text { Back-arc Arc } \\ \text { (future Nahlin ophiolite) }\end{gathered}$

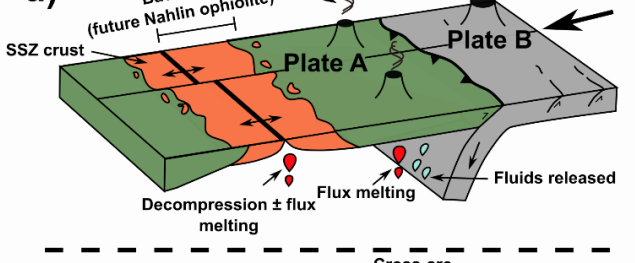

- - - - - - - - $\bar{c}$ cross-arc

e)

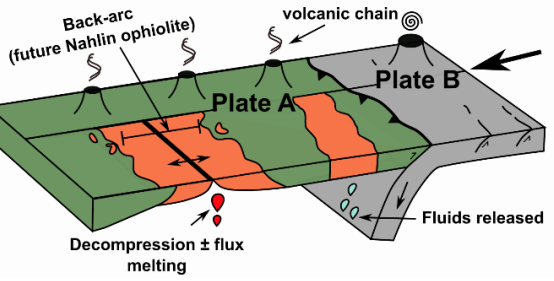


Table 2 - Supplemental - Lithogeochemical Data for Igneous Rocks of the Menetatauline Area

\begin{tabular}{|c|c|c|c|c|c|c|}
\hline Sample & 15ZE-0943 & 15ZE-0944 & 15ZE953 & 15ZE955 & 15ZE-0985 & ZE15SM030 \\
\hline Latitude & 58.921 & 58.915 & 58.878 & 58.881 & 60.328 & 58.935 \\
\hline Longitude & -132.294 & -132.291 & -132.371 & -132.381 & -133.323 & -132.260 \\
\hline Rock type & Mafic volcanic & Mafic volcanic & Mafic volcanic & Mafic volcanic & Mafic volcanic & $\begin{array}{c}\text { Mafic } \\
\text { volcaniclastic }\end{array}$ \\
\hline Affinity & IAT & IAT & IAT & IAT & IAT & IAT \\
\hline $\mathrm{SiO} 2$ & 50.17 & 51.13 & 52.81 & 59.62 & 52.01 & 51.08 \\
\hline $\mathrm{Al} 2 \mathrm{O} 3$ & 15.43 & 14.93 & 15.60 & 15.85 & 14.30 & 14.70 \\
\hline $\mathrm{Fe} 2 \mathrm{O} 3$ & 10.80 & 10.28 & 13.11 & 10.33 & 13.79 & 10.68 \\
\hline $\mathrm{MnO}$ & 0.17 & 0.17 & 0.10 & 0.14 & 0.22 & 0.16 \\
\hline $\mathrm{MgO}$ & 6.47 & 8.37 & 8.39 & 4.78 & 5.21 & 8.70 \\
\hline $\mathrm{CaO}$ & 12.63 & 10.30 & 4.14 & 2.53 & 7.63 & 9.09 \\
\hline $\mathrm{Na} 2 \mathrm{O}$ & 2.62 & 3.00 & 2.50 & 5.99 & 4.07 & 3.79 \\
\hline K2O & 0.12 & 0.55 & 1.77 & 0.07 & 0.54 & 0.27 \\
\hline $\mathrm{TiO} 2$ & 1.45 & 1.18 & 1.49 & 0.62 & 2.02 & 1.36 \\
\hline P2O5 & 0.13 & 0.11 & 0.10 & 0.06 & 0.19 & 0.14 \\
\hline $\mathrm{Cr} 2 \mathrm{O} 3$ & 0.04 & 0.05 & 0.03 & 0.01 & 0.02 & 0.05 \\
\hline Total & 100.00 & 100.01 & 100.00 & 99.99 & 99.99 & 99.98 \\
\hline Cs & n.d. & 0.3 & 1.1 & 0.2 & 4.5 & 0.3 \\
\hline $\mathrm{Rb}$ & 2 & 12 & 22 & n.d. & 14 & 5 \\
\hline $\mathrm{Sr}$ & 49 & 38 & 194 & 25 & 97 & 81 \\
\hline $\mathrm{Ba}$ & 14 & 34 & 301 & 17 & 781 & 20 \\
\hline Y & 31.4 & 25.3 & 22.5 & 11.5 & 45.9 & 27.2 \\
\hline $\mathrm{Zr}$ & 79 & 66 & 92 & 43 & 108 & 97 \\
\hline $\mathrm{Hf}$ & 2.1 & 1.8 & 2 & 0.9 & 2.7 & 2.1 \\
\hline $\mathrm{Nb}$ & 0.7 & 1.3 & 1.2 & 1 & 3.2 & 2.2 \\
\hline $\mathrm{Ta}$ & 0.14 & 0.37 & 0.04 & 0.04 & 0.37 & 0.13 \\
\hline $\mathrm{Sc}$ & 41 & 35 & 35 & 32 & 41 & 37 \\
\hline V & 318 & 264 & 366 & 184 & 393 & 288 \\
\hline $\mathrm{Ni}$ & 80 & 190 & 130 & 40 & 70 & 180 \\
\hline $\mathrm{Cu}$ & 70 & 60 & 50 & n.d. & 80 & 80 \\
\hline $\mathrm{Zn}$ & 80 & 70 & 90 & 70 & 120 & 90 \\
\hline W & n.d. & 1.8 & 0.6 & 0.6 & 1.8 & 0.7 \\
\hline As & n.d. & n.d. & n.d. & n.d. & n.d. & n.d. \\
\hline TI & n.d. & 0.08 & n.d. & n.d. & 0.14 & n.d. \\
\hline $\mathrm{Pb}$ & n.d. & n.d. & n.d. & n.d. & n.d. & n.d. \\
\hline Th & 0.11 & 0.16 & 0.15 & 0.2 & 0.25 & 0.22 \\
\hline U & 0.18 & 0.11 & 0.09 & 0.15 & 0.14 & 0.14 \\
\hline La & 2.81 & 2.03 & 2.49 & 1.78 & 3.14 & 4.35 \\
\hline $\mathrm{Ce}$ & 9.2 & 6.91 & 8.17 & 4.53 & 10.8 & 12.4 \\
\hline $\mathrm{Pr}$ & 1.57 & 1.29 & 1.4 & 0.69 & 1.99 & 1.94 \\
\hline $\mathrm{Nd}$ & 9.13 & 7.22 & 7.5 & 3.4 & 11.2 & 10.1 \\
\hline $\mathrm{Sm}$ & 3.36 & 2.76 & 2.72 & 1.14 & 4.36 & 3.38 \\
\hline $\mathrm{Eu}$ & 1.29 & 1.04 & 1.05 & 0.433 & 1.64 & 1.06 \\
\hline $\mathrm{Gd}$ & 4.68 & 3.8 & 3.49 & 1.68 & 6.37 & 4.34 \\
\hline $\mathrm{Tb}$ & 0.88 & 0.71 & 0.62 & 0.31 & 1.15 & 0.76 \\
\hline Dy & 5.64 & 4.46 & 4.13 & 2.18 & 8.25 & 5.11 \\
\hline $\mathrm{Ho}$ & 1.16 & 0.95 & 0.83 & 0.46 & 1.69 & 1.04 \\
\hline $\mathrm{Er}$ & 3.35 & 2.69 & 2.5 & 1.38 & 4.93 & 3.02 \\
\hline $\mathrm{Tm}$ & 0.501 & 0.413 & 0.348 & 0.229 & 0.758 & 0.462 \\
\hline $\mathrm{Yb}$ & 3.26 & 2.64 & 2.22 & 1.56 & 4.95 & 2.87 \\
\hline $\mathrm{Lu}$ & 0.52 & 0.404 & 0.336 & 0.213 & 0.739 & 0.447 \\
\hline
\end{tabular}




\begin{tabular}{|c|c|c|c|c|c|c|}
\hline ZE15SM031A & ZE15SM039B & ZE15SM040 & ZE15SM105 & 16SM 167 & 16SM 172 & ZE15SM033 \\
\hline 58.932 & 58.962 & 58.959 & 58.964 & 58.885 & 58.869 & 58.936 \\
\hline-132.257 & -132.214 & -132.212 & -132.734 & -132.188 & -132.167 & -132.246 \\
\hline $\begin{array}{c}\text { Mafic } \\
\text { volcaniclastic }\end{array}$ & Mafic volcanic & $\begin{array}{c}\text { Mafic } \\
\text { volcaniclastic }\end{array}$ & Mafic volcanic & $\begin{array}{c}\text { Ultramafic } \\
\text { volcaniclastic }\end{array}$ & $\begin{array}{c}\text { Mafic } \\
\text { volcaniclastic }\end{array}$ & Diabasic dike \\
\hline IAT & IAT & IAT & IAT & IAT & IAT & IAT \\
\hline 50.50 & 50.68 & 51.19 & 47.57 & 47.71 & 50.03 & 54.62 \\
\hline 16.05 & 14.38 & 15.01 & 13.81 & 8.03 & 17.14 & 14.97 \\
\hline 8.88 & 10.63 & 10.87 & 13.48 & 12.16 & 15.40 & 11.55 \\
\hline 0.15 & 0.18 & 0.18 & 0.22 & 0.24 & 0.27 & 0.16 \\
\hline 7.08 & 8.22 & 6.72 & 5.61 & 20.58 & 3.74 & 4.52 \\
\hline 14.23 & 11.93 & 10.80 & 13.18 & 9.91 & 6.53 & 8.03 \\
\hline 1.85 & 2.04 & 3.39 & 3.87 & 0.30 & 4.34 & 4.78 \\
\hline 0.20 & 0.21 & 0.33 & 0.25 & 0.02 & 0.68 & 0.15 \\
\hline 0.98 & 1.56 & 1.41 & 1.85 & 0.96 & 1.73 & 1.10 \\
\hline 0.06 & 0.16 & 0.10 & 0.19 & 0.09 & 0.15 & 0.10 \\
\hline 0.04 & 0.05 & 0.02 & 0.02 & 0.20 & 0.09 & 0.01 \\
\hline 99.99 & 99.99 & 100.01 & 100.03 & 100.00 & 100.00 & 100.00 \\
\hline 0.1 & 0.1 & 0.2 & 0.2 & 0.2 & 0.4 & n.d. \\
\hline 3 & 4 & 3 & 2 & n.d. & 13 & 2 \\
\hline 53 & 151 & 94 & 424 & 18 & 90 & 137 \\
\hline 9 & 9 & 49 & 149 & 9 & 124 & 19 \\
\hline 20.7 & 31.6 & 28 & 37.9 & 22.7 & 26.3 & 19.3 \\
\hline 54 & 114 & 81 & 123 & 53 & 88 & 68 \\
\hline 1.2 & 2.4 & 1.8 & 2.8 & 1.4 & 2.4 & 1.6 \\
\hline 0.8 & 2.2 & 1.2 & 3.4 & 0.9 & 2.5 & 0.9 \\
\hline n.d. & 0.11 & 0.04 & 0.19 & 0.07 & 0.19 & 0.02 \\
\hline 36 & 35 & 37 & 37 & 39 & 33 & 34 \\
\hline 261 & 303 & 317 & 379 & 229 & 277 & 359 \\
\hline 110 & 170 & 70 & 60 & 460 & 280 & 40 \\
\hline 70 & 50 & 60 & 60 & 40 & 70 & 60 \\
\hline 60 & 60 & 80 & 100 & 110 & 210 & 90 \\
\hline 0.6 & n.d. & 0.5 & n.d. & n.d. & n.d. & n.d. \\
\hline n.d. & n.d. & n.d. & n.d. & n.d. & 10 & n.d. \\
\hline n.d. & n.d. & n.d. & n.d. & n.d. & n.d. & n.d. \\
\hline n.d. & n.d. & n.d. & 7 & n.d. & n.d. & 28 \\
\hline 0.08 & 0.21 & 0.1 & 0.48 & 0.15 & 0.28 & 0.17 \\
\hline 0.12 & 0.12 & 0.05 & 0.2 & 0.18 & 0.32 & 0.11 \\
\hline 2.02 & 4.53 & 2.63 & 6.58 & 2.34 & 5.32 & 2.88 \\
\hline 6.34 & 13.7 & 8.69 & 17.9 & 6.48 & 11.6 & 8.51 \\
\hline 1.09 & 2.13 & 1.51 & 2.75 & 1.02 & 1.94 & 1.37 \\
\hline 5.9 & 11.3 & 8.51 & 13.8 & 5.47 & 10.2 & 7.27 \\
\hline 2.15 & 3.91 & 2.98 & 4.52 & 1.94 & 3.39 & 2.4 \\
\hline 0.928 & 1.29 & 1.08 & 1.55 & 0.694 & 1.28 & 0.979 \\
\hline 3.17 & 4.94 & 4.2 & 6.16 & 2.85 & 4.5 & 3.23 \\
\hline 0.56 & 0.92 & 0.76 & 1.03 & 0.53 & 0.76 & 0.54 \\
\hline 3.71 & 5.81 & 5.01 & 6.82 & 3.57 & 4.83 & 3.62 \\
\hline 0.8 & 1.21 & 1.06 & 1.43 & 0.78 & 0.96 & 0.77 \\
\hline 2.28 & 3.47 & 3.07 & 4.11 & 2.35 & 2.69 & 2.21 \\
\hline 0.362 & 0.506 & 0.452 & 0.589 & 0.33 & 0.363 & 0.346 \\
\hline 2.34 & 3.36 & 2.97 & 3.96 & 2.14 & 2.34 & 2.34 \\
\hline 0.346 & 0.507 & 0.471 & 0.621 & 0.339 & 0.375 & 0.338 \\
\hline
\end{tabular}




\begin{tabular}{|c|c|c|c|c|c|c|}
\hline ZE15SM054A & $16 S M 161$ & $16 S M 163$ & 16SM 178 & $16 S M 186$ & ZE15AC062 & ZE15SM050 \\
\hline 58.948 & 58.902 & 58.899 & 58.863 & 58.878 & 58.961 & 58.971 \\
\hline-132.254 & -132.169 & -132.171 & -132.114 & -132.143 & -132.764 & -132.239 \\
\hline Diabasic dike & Gabbroic dike & $\begin{array}{l}\text { Amph-bearing } \\
\text { gabbroic dike }\end{array}$ & $\begin{array}{l}\text { Amph-bearing } \\
\text { gabbroic dike }\end{array}$ & Gabbroic dike & Gabbro & Gabbro \\
\hline IAT & IAT & IAT & IAT & IAT & IAT & IAT \\
\hline 55.21 & 52.57 & 55.08 & 54.28 & 50.72 & 53.95 & 44.25 \\
\hline 15.28 & 16.57 & 14.91 & 14.69 & 16.84 & 14.14 & 9.32 \\
\hline 11.87 & 7.89 & 8.67 & 11.86 & 9.20 & 12.55 & 10.69 \\
\hline 0.17 & 0.13 & 0.13 & 0.20 & 0.15 & 0.20 & 0.19 \\
\hline 4.36 & 7.71 & 7.26 & 4.21 & 7.77 & 5.23 & 7.87 \\
\hline 8.98 & 10.03 & 8.32 & 8.50 & 9.78 & 6.30 & 21.34 \\
\hline 2.87 & 4.04 & 4.13 & 4.76 & 3.19 & 5.55 & 4.74 \\
\hline 0.14 & 0.41 & 0.52 & 0.10 & 1.33 & 0.21 & 0.13 \\
\hline 1.01 & 0.58 & 0.87 & 1.29 & 0.95 & 1.66 & 1.39 \\
\hline 0.10 & 0.05 & 0.10 & 0.13 & 0.06 & 0.15 & 0.13 \\
\hline 0.01 & 0.01 & 0.02 & & 0.04 & 0.02 & 0.04 \\
\hline 100.00 & 99.98 & 100.00 & 100.02 & 100.00 & 99.95 & 100.03 \\
\hline n.d. & n.d. & 0.1 & n.d. & 0.1 & 0.2 & 0.3 \\
\hline n.d. & 7 & 7 & n.d. & 14 & 3 & 4 \\
\hline 162 & 223 & 218 & 171 & 365 & 142 & 27 \\
\hline 27 & 40 & 51 & 27 & 30 & 24 & n.d. \\
\hline 20.2 & 12.6 & 20.8 & 26.7 & 24.2 & 35 & 27 \\
\hline 69 & 43 & 65 & 78 & 57 & 99 & 78 \\
\hline 1.6 & 1.1 & 1.8 & 2.2 & 1.7 & 2.3 & 1.7 \\
\hline 0.8 & n.d. & 1 & 0.9 & 0.8 & 1 & 1.3 \\
\hline n.d. & 0.01 & 0.08 & 0.08 & 0.06 & n.d. & 0.05 \\
\hline 35 & 36 & 32 & 32 & 35 & 33 & 38 \\
\hline 357 & 185 & 234 & 333 & 227 & 297 & 306 \\
\hline 30 & 90 & 60 & 40 & 120 & 100 & 120 \\
\hline 40 & 120 & 60 & 60 & 60 & 40 & 50 \\
\hline 80 & 50 & 50 & 70 & 60 & 100 & 70 \\
\hline 0.7 & n.d. & n.d. & n.d. & n.d. & 0.7 & 0.7 \\
\hline n.d. & n.d. & n.d. & n.d. & n.d. & n.d. & n.d. \\
\hline n.d. & n.d. & n.d. & n.d. & n.d. & n.d. & n.d. \\
\hline n.d. & n.d. & n.d. & n.d. & n.d. & 33 & n.d. \\
\hline 0.18 & 0.12 & 0.25 & 0.23 & 0.08 & 0.15 & 0.13 \\
\hline 0.11 & 0.07 & 0.15 & 0.16 & 0.04 & 0.1 & 0.05 \\
\hline 2.87 & 1.45 & 2.89 & 3.08 & 2.16 & 3.12 & 2.85 \\
\hline 8.36 & 4.51 & 7.95 & 9.1 & 6.86 & 10.6 & 9.08 \\
\hline 1.35 & 0.77 & 1.19 & 1.5 & 1.14 & 1.87 & 1.48 \\
\hline 7.06 & 4.04 & 6.57 & 8.03 & 6.51 & 10.3 & 8.35 \\
\hline 2.49 & 1.42 & 2.25 & 2.82 & 2.43 & 3.83 & 2.92 \\
\hline 0.92 & 0.554 & 0.803 & 1 & 1.02 & 1.4 & 1.14 \\
\hline 3.16 & 1.83 & 2.86 & 3.7 & 3.32 & 5.32 & 4.16 \\
\hline 0.57 & 0.31 & 0.5 & 0.68 & 0.61 & 0.97 & 0.77 \\
\hline 3.6 & 2.04 & 3.35 & 4.47 & 4.06 & 6.34 & 4.89 \\
\hline 0.78 & 0.43 & 0.71 & 0.94 & 0.87 & 1.33 & 1.02 \\
\hline 2.24 & 1.26 & 2.04 & 2.75 & 2.48 & 3.88 & 3.14 \\
\hline 0.356 & 0.187 & 0.311 & 0.404 & 0.346 & 0.583 & 0.458 \\
\hline 2.25 & 1.16 & 2.02 & 2.65 & 2.33 & 3.93 & 2.89 \\
\hline 0.335 & 0.185 & 0.329 & 0.427 & 0.373 & 0.584 & 0.457 \\
\hline
\end{tabular}




\begin{tabular}{|c|c|c|c|c|c|c|}
\hline ZE15SM090 & 15ZE956A & 15ZE959A & 15ZE965 & 15ZE971 & ZE15SM112A & 15ZE-0945 \\
\hline 58.973 & 58.886 & 58.892 & 58.899 & 58.960 & 58.980 & 58.912 \\
\hline-132.679 & -132.373 & -132.390 & -132.391 & -132.382 & -132.698 & -132.290 \\
\hline $\begin{array}{l}\text { Amph-bearing } \\
\text { gabbro }\end{array}$ & $\begin{array}{l}\text { Gabbronorite } \\
\text { cumulate }\end{array}$ & $\begin{array}{c}\text { Gabbronorite } \\
\text { cumulate }\end{array}$ & $\begin{array}{l}\text { Plag-bearing olivine } \\
\text { websterite cumulate }\end{array}$ & Mafic volcanic & Mafic volcanic & Mafic volcanic \\
\hline IAT & IAT & IAT & IAT & OIB & OIB & EMORB \\
\hline 52.12 & 45.60 & 49.55 & 43.47 & 48.32 & 40.38 & 46.56 \\
\hline 13.44 & 15.63 & 14.22 & 10.73 & 16.50 & 14.09 & 19.10 \\
\hline 13.26 & 7.36 & 5.90 & 3.63 & 10.33 & 5.90 & 12.24 \\
\hline 0.20 & 0.13 & 0.11 & 0.03 & 0.18 & 0.07 & 0.21 \\
\hline 5.76 & 11.99 & 13.22 & 36.56 & 7.15 & 3.66 & 7.04 \\
\hline 8.39 & 18.57 & 15.48 & 5.24 & 11.83 & 27.40 & 11.05 \\
\hline 4.47 & 0.42 & 1.28 & 0.18 & 3.16 & 3.58 & 1.58 \\
\hline 0.45 & 0.04 & 0.06 & 0.01 & 0.19 & 2.12 & 0.45 \\
\hline 1.81 & 0.23 & 0.18 & 0.15 & 2.10 & 1.84 & 1.59 \\
\hline 0.09 & - & 0.01 & - & 0.25 & 0.95 & 0.18 \\
\hline 0.02 & 0.08 & 0.11 & 0.56 & 0.01 & 0.04 & 0.05 \\
\hline 99.99 & 99.98 & 100.02 & 100.01 & 100.02 & 99.98 & 100.00 \\
\hline 0.5 & n.d. & n.d. & n.d. & 0.6 & 2.7 & 0.2 \\
\hline 6 & n.d. & n.d. & n.d. & 7 & 35 & 10 \\
\hline 118 & 257 & 323 & 4 & 136 & 159 & 620 \\
\hline 24 & 12 & 13 & 4 & 43 & 275 & 44 \\
\hline 28.5 & 6.2 & 4.3 & 2.1 & 21.7 & 18.5 & 28.5 \\
\hline 77 & 5 & 9 & 7 & 138 & 107 & 101 \\
\hline 1.8 & 0.2 & 0.2 & n.d. & 3 & 2.1 & 2.3 \\
\hline 0.9 & n.d. & 0.4 & 4.2 & 24.6 & 18.5 & 6.8 \\
\hline n.d. & 0.04 & n.d. & 0.05 & 2.12 & 1.27 & 0.6 \\
\hline 37 & 40 & 41 & 11 & 36 & 20 & 46 \\
\hline 474 & 138 & 150 & 74 & 277 & 160 & 274 \\
\hline 90 & 240 & 320 & 1110 & 60 & 80 & 140 \\
\hline 40 & 130 & 80 & 10 & 100 & 40 & 90 \\
\hline 90 & 40 & n.d. & n.d. & 80 & 40 & 130 \\
\hline n.d. & n.d. & n.d. & 0.6 & 1.8 & 1.1 & n.d. \\
\hline n.d. & n.d. & n.d. & n.d. & 9 & n.d. & n.d. \\
\hline n.d. & n.d. & n.d. & n.d. & n.d. & 0.07 & 0.07 \\
\hline n.d. & n.d. & 35 & 11 & n.d. & n.d. & n.d. \\
\hline 0.11 & n.d. & 0.06 & 0.5 & 1.7 & 1.47 & 0.63 \\
\hline 0.07 & n.d. & 0.02 & 0.01 & 0.5 & 0.52 & 0.26 \\
\hline 2.6 & 0.28 & 0.4 & 0.22 & 16.2 & 21.9 & 8.25 \\
\hline 8.51 & 0.74 & 1.04 & 0.62 & 35.7 & 40.9 & 19.1 \\
\hline 1.44 & 0.15 & 0.15 & 0.11 & 4.45 & 4.67 & 2.61 \\
\hline 8.6 & 1.02 & 0.85 & 0.46 & 18.7 & 19.8 & 12.3 \\
\hline 3.09 & 0.48 & 0.38 & 0.22 & 4.34 & 4.41 & 3.61 \\
\hline 1.2 & 0.335 & 0.201 & 0.013 & 1.55 & 1.46 & 1.47 \\
\hline 4.17 & 0.82 & 0.6 & 0.22 & 4.47 & 4.27 & 4.53 \\
\hline 0.81 & 0.16 & 0.11 & 0.04 & 0.7 & 0.62 & 0.79 \\
\hline 5.23 & 1.09 & 0.8 & 0.32 & 4.23 & 3.64 & 5.18 \\
\hline 1.09 & 0.25 & 0.18 & 0.07 & 0.79 & 0.66 & 1.06 \\
\hline 3.2 & 0.68 & 0.55 & 0.21 & 2.23 & 1.81 & 2.98 \\
\hline 0.487 & 0.101 & 0.083 & 0.037 & 0.329 & 0.235 & 0.443 \\
\hline 3.18 & 0.62 & 0.52 & 0.28 & 1.9 & 1.47 & 2.95 \\
\hline 0.498 & 0.091 & 0.075 & 0.046 & 0.279 & 0.21 & 0.438 \\
\hline
\end{tabular}




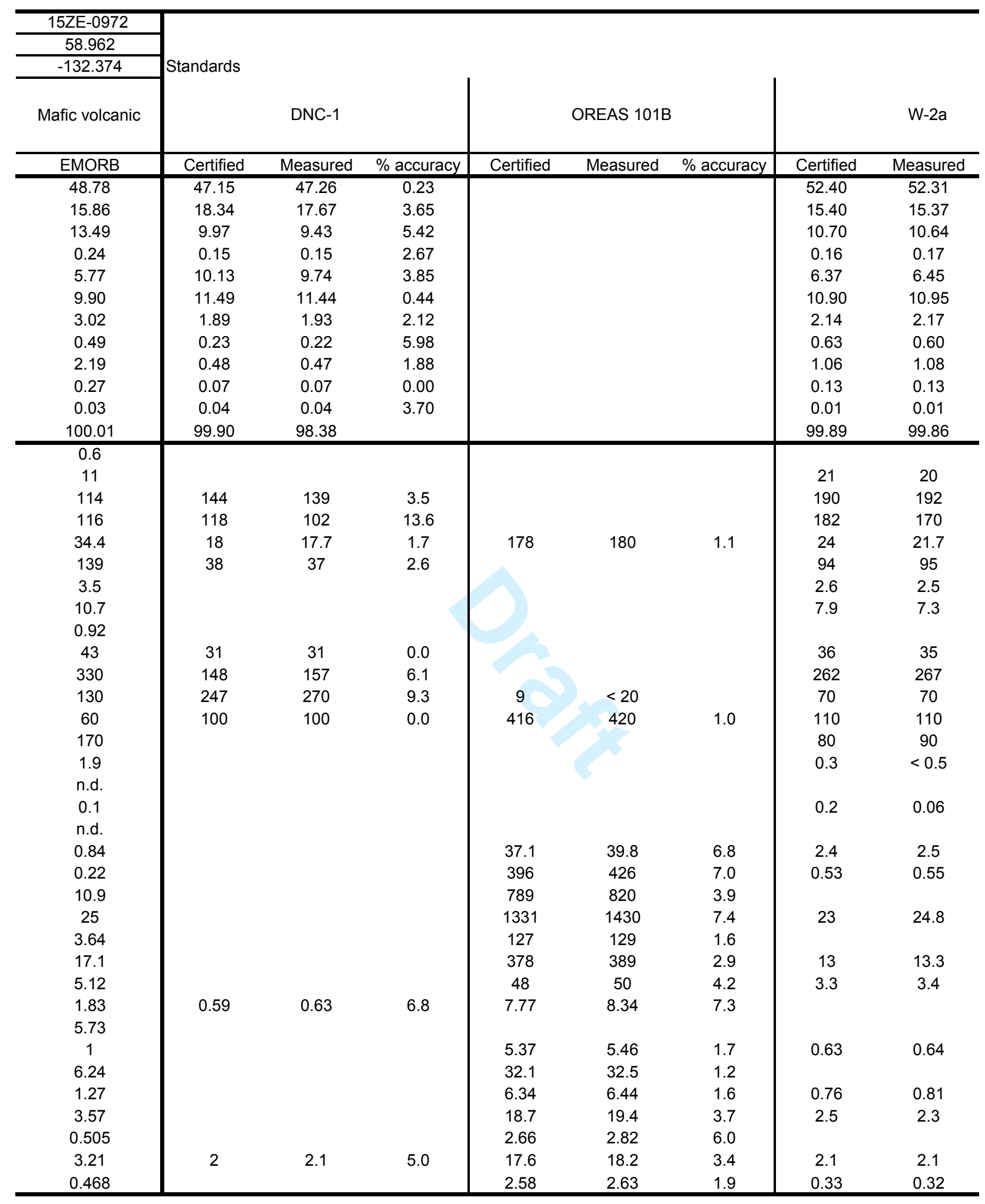


1.26

0.46

1.40

4.15

1.51

0.00

8.70

4.8

1.1

6.6

9.6

1.1

3.8

7.6

2.8

1.9

0.0

0.0

12.5

70.0

4.2

3.8

7.8

2.3

3.0

1.6

6.6

8.0

0.0

3.0

https://mc06.manuscriptcentral.com/cjes-pubs 


\begin{tabular}{|c|c|c|c|c|c|c|c|c|c|}
\hline \multirow[t]{2}{*}{ Standard } & \multicolumn{3}{|c|}{ DNC-1 } & \multicolumn{3}{|c|}{ OREAS 101B } & \multicolumn{3}{|c|}{ W-2a } \\
\hline & Certified & Measured & $\%$ accuracy & Certified & Measured & $\%$ accuracy & Certified & Measured & $\%$ accuracy \\
\hline $\mathrm{SiO} 2$ & 47.15 & 47.26 & 0.23 & & & & 52.40 & 52.31 & 0.17 \\
\hline $\mathrm{Al} 2 \mathrm{O} 3$ & 18.34 & 17.67 & 3.65 & & & & 15.40 & 15.37 & 0.19 \\
\hline $\mathrm{Fe} 2 \mathrm{O} 3$ & 9.97 & 9.43 & 5.42 & & & & 10.70 & 10.64 & 0.56 \\
\hline $\mathrm{MnO}$ & 0.15 & 0.15 & 2.67 & & & & 0.16 & 0.17 & 1.23 \\
\hline $\mathrm{MgO}$ & 10.13 & 9.74 & 3.85 & & & & 6.37 & 6.45 & 1.26 \\
\hline $\mathrm{CaO}$ & 11.49 & 11.44 & 0.44 & & & & 10.90 & 10.95 & 0.46 \\
\hline $\mathrm{Na} 2 \mathrm{O}$ & 1.89 & 1.93 & 2.12 & & & & 2.14 & 2.17 & 1.40 \\
\hline K2O & 0.23 & 0.22 & 5.98 & & & & 0.63 & 0.60 & 4.15 \\
\hline $\mathrm{TiO} 2$ & 0.48 & 0.47 & 1.88 & & & & 1.06 & 1.08 & 1.51 \\
\hline P2O5 & 0.07 & 0.07 & 0.00 & & & & 0.13 & 0.13 & 0.00 \\
\hline $\mathrm{Cr} 2 \mathrm{O} 3$ & 0.04 & 0.04 & 3.70 & & & & 0.01 & 0.01 & 8.70 \\
\hline Total & 99.90 & 98.38 & & & & & 99.89 & 99.86 & \\
\hline \multicolumn{10}{|l|}{ Cs } \\
\hline $\mathrm{Rb}$ & & & & & & & 21 & 20 & 4.8 \\
\hline $\mathrm{Sr}$ & 144 & 139 & 3.5 & & & & 190 & 192 & 1.1 \\
\hline $\mathrm{Ba}$ & 118 & 102 & 13.6 & & & & 182 & 170 & 6.6 \\
\hline Y & 18 & 17.7 & 1.7 & 178 & 180 & 1.1 & 24 & 21.7 & 9.6 \\
\hline $\mathrm{Zr}$ & 38 & 37 & 2.6 & & & & 94 & 95 & 1.1 \\
\hline $\mathrm{Hf}$ & & & & & & & 2.6 & 2.5 & 3.8 \\
\hline $\mathrm{Nb}$ & & & & & & & 7.9 & 7.3 & 7.6 \\
\hline \multicolumn{10}{|l|}{$\mathrm{Ta}$} \\
\hline $\mathrm{Sc}$ & 31 & 31 & 0.0 & & & & 36 & 35 & 2.8 \\
\hline V & 148 & 157 & 6.1 & & & & 262 & 267 & 1.9 \\
\hline $\mathrm{Cr}$ & 270 & 280 & 3.7 & & & & 92 & 100 & 8.7 \\
\hline $\mathrm{Ni}$ & 247 & 270 & 9.3 & 9 & $<20$ & & 70 & 70 & 0.0 \\
\hline $\mathrm{Cu}$ & 100 & 100 & 0.0 & 416 & 420 & 1.0 & 110 & 110 & 0.0 \\
\hline$Z n$ & & & & & & & 80 & 90 & 12.5 \\
\hline W & & & & & & & 0.3 & $<0.5$ & \\
\hline \multicolumn{10}{|l|}{ As } \\
\hline $\mathrm{TI}$ & & & & & & & 0.2 & 0.06 & 70.0 \\
\hline \multicolumn{10}{|l|}{$\mathrm{Pb}$} \\
\hline Th & & & & 37.1 & 39.8 & 6.8 & 2.4 & 2.5 & 4.2 \\
\hline$U$ & & & & 396 & 426 & 7.0 & 0.53 & 0.55 & 3.8 \\
\hline La & & & & 789 & 820 & 3.9 & & & \\
\hline $\mathrm{Ce}$ & & & & 1331 & 1430 & 7.4 & 23 & 24.8 & 7.8 \\
\hline $\operatorname{Pr}$ & & & & 127 & 129 & 1.6 & & & \\
\hline $\mathrm{Nd}$ & & & & 378 & 389 & 2.9 & 13 & 13.3 & 2.3 \\
\hline $\mathrm{Sm}$ & & & & 48 & 50 & 4.2 & 3.3 & 3.4 & 3.0 \\
\hline $\mathrm{Eu}$ & 0.59 & 0.63 & 6.8 & 7.77 & 8.34 & 7.3 & & & \\
\hline \multicolumn{10}{|l|}{$\mathrm{Gd}$} \\
\hline $\mathrm{Tb}$ & & & & 5.37 & 5.46 & 1.7 & 0.63 & 0.64 & 1.6 \\
\hline
\end{tabular}




\begin{tabular}{|c|c|c|c|c|c|c|c|c|c|}
\hline Dy & & & & 32.1 & 32.5 & 1.2 & & & \\
\hline Ho & & & & 6.34 & 6.44 & 1.6 & 0.76 & 0.81 & 6.6 \\
\hline $\mathrm{Er}$ & & & & 18.7 & 19.4 & 3.7 & 2.5 & 2.3 & 8.0 \\
\hline $\mathrm{Tm}$ & & & & 2.66 & 2.82 & 6.0 & & & \\
\hline $\mathrm{Yb}$ & 2 & 2.1 & 5.0 & 17.6 & 18.2 & 3.4 & 2.1 & 2.1 & 0.0 \\
\hline Lu & & & & 2.58 & 2.63 & 1.9 & 0.33 & 0.32 & 3.0 \\
\hline
\end{tabular}

